\title{
An Assessment on the Impact of Training and Development on Employees' Performance in the Namibian Defence Force at Okahandja
}

\author{
Ingrid Zemburuka \\ Coordination Division, Namibia Command and Staff College \\ P.O. Box 2167, Okahandja \\ E-mail: zemburukaingrid@gmail.com \\ Fanuel Dangarembizi (Corresponding Author) \\ Department of Management Sciences, University of Namibia \\ Private Bag 13301, Windhoek \\ E-mail: fanuel2020@yahoo.com
}

Received: June 17, 2020 Accepted: July 23, 2020 Online published: August 6, 2020

doi:10.5296/ijhrs.v10i3.17496 URL: https://doi.org/10.5296/ijhrs.v10i3.17496

\begin{abstract}
The study focused on assessing the impact of training and development on employee performance in the Namibia Defence Force (NDF) at Okahandja. Since its inception, the NDF has been providing continuous training and development programs to pursue the organizational mission \& vision. Sadly, for the past two (2) years when the organization started facing financial challenges; it suspended most of its training activities both internal and external. This, in turn, has affected employees' performance who should be continuously trained during peacetime to upgrade their skills, knowledge, and competencies needed to perform their duties professionally. The study employed descriptive research design to draw a sample of 100 employees from a population of 500 employees. Correlation analysis was used to establish relationship between training, development, and employee's performance. The study found out that there was positive relationship between training and development with employee's and NDF performance. It also revealed that employee's performance increased the way the NDF staffs works with other government agencies across the country. Therefore, the NDF should seek to prioritize their training and development (T\&D) programmes based
\end{abstract}


on the training budget and avoid random cost cutting.

Keywords: training and development, employee performance, kirkpatrick training evaluation model, Brinkerhoff's six- stage model of evaluation

\section{Introduction}

The concept of training predates history and has been there since the evaluation of man. According to Gomez-Mejia, Balkin, \& Cardy (2010), training and development (T\&D) can be defined as a systematic process of acquiring knowledge, skills, abilities and the right attitudes and behaviours to meet the job requirements in an organization. Noe, Hollenbeck, Gerhart \& Wright (2012) also reiterated that T\&D teach employees how to perform their jobs professionally and preparing for future responsibilities. Nowadays, changes in technology, political and economic environments have increased competition amongst organizations due to globalization. Noe et al. (2012) further stated that, these had prompted organizations to train their employees and thus in turn enhances organizational performance. In line with this, organizations need to develop, organize, and manage their human capital effectively and efficiently to stay afloat, survive and be competitive. This, therefore, calls for managers to have adequate pool of staffs that are competent and capable of career progression into specialist departments or managerial positions (Afshan, Sobia, Kamran \& Nasir, 2012).

On the other hand, Cole (2013) argued that training differs from organization to organization depending on the degree of internal and external changes that occurs within the environment. Training is, therefore, an effort initiated by an organization to foster learning amongst workers whilst development is an effort oriented more towards broadening an individual's skills for future responsibility (George $\&$ Scott, 2012). In a bid to achieve positive results, the NDF also effectively used T\&D programmes to improve their employees' competence as well as performance. They worked with other countries as well as local institutions to ensure that their employees get the requisite training needed to improve individual's performance. However, the question remains that even though the NDF understands and have been practicing $\mathrm{T} \& \mathrm{D}$; does it addresses employees' training needs accordingly when faced with economic challenges.

Empirical studies documented that there was a positive relationship between training and development on employee' performance (e.g. Elnaga \& Imran, 2013; Sandamali et al., 2018; Sendawula et al., 2018; Imran \& Tanveer, 2015; Sanyal \& Hisam, 2016; Sulana, 2012; Nassazi, 2013). Regardless of the growing phenomenon of T\&D around the globe; many of these studies covered mostly banking and telecommunications and not security sector. Furthermore, there have been few studies on T\&D in the Namibian context. Therefore, this study presents a unique opportunity to contribute to the body of knowledge in an area that has not been researched before with regards to the NDF.

The main research questions are: how important is training and development to the employees' performance? What is the significance of employee performance to an organization? What is the relationship between training and development to employee's performance? The study used correlation analysis to establish relationship between training, 
development, and employee's performance. Descriptive research design was used to draw a sample of 100 employees from a population of 500 employees. The study found out that there was positive relationship between training and development with employee's and NDF performance. It also revealed that employee's performance increased the way NDF staffs works with other government agencies across the country.

The introduction gives a brief overview of training and development activities in the NDF. Section 2 discusses the literature review critically analyzing the existing knowledge on the subject. Section 3 presents the research methodology while section 4 presents and analyses the results of the study. Section 5 concludes the study and provides policy recommendations.

\subsection{Explore Importance of the Problem}

This study began from realization of the need to effectively administer the effect of training and development on employee's performance within the NDF at Okahandja. Training and development enhance employee's skills, knowledge, and competency that are necessary to perform on the job. On the other hand, training impacts on organizational competitiveness, revenue, and performance. Since its inception, the NDF has been providing continuous training and development programs to pursue the organizational mission \& vision. Sadly, for the past two (2) years when the organization started facing some financial challenges; the NDF suspended most training activities both internal and external. This, in turn, has affected employees' performance as they should be trained during peacetime to upgrade their skills, knowledge, and competencies to perform their duties professionally. Furthermore, the lack of training and development has increased indiscipline cases among the force coupled with high rate of turnover. Thus, the aim of this study is to investigate how the NDF sees training within the organization and how it has impacted on employees' performance.

\section{Review of the Literature}

\subsection{Training and Training and Development}

T\&D refer to the process required to obtain, or transfer knowledge, skills and abilities needed to carry out a specific activity or task (Olumuyiwa, Adelaja \& Chukwuemeka 2012). A similar view was expressed by Nischithaa \& Narasimba-Rao (2014) that training are designed to provide learners with the knowledge and skills needed in their present jobs whereas development is the learning that goes beyond the current job and has a long-term focus. Thus, the difference is that training can be done by all staffs whilst development is mostly undertaken by the supervisors or managers (Nischithaa et al., 2014). Equally, Tshikovhi (2012) defines training as a learning undertaken to enable an effective job performance and maintain operational capability in employment whereas development is a learning that changes a person to grow individually. Therefore, T\&D is a planned effort designed to improve the employees' competency and performance (Engetou, 2017).

According to Chinomnso (2014) numerous authors viewed T\&D as having the ability and capacity to develop employees. This sentiment proposes that T\&D must be able to address employee's training needs. Bratton \& Gold (2000) also contended that successful leaderships and competitive advantage in organizations to human capital. However, they claimed that, 
only few companies know how to manage their human capital effectively by using traditional approach of people management which no longer applies within the dynamic environments. Therefore, all organizations be it small or large, private, or public entities needs employees who are highly competent and skilled.

Contrary, the formal education system in Namibia does not teach specific job skills needed by employers for various positions (Naanda, 2010). Considering this, various employees need massive $T \& D$ programmes on the job to acquire the needed skills and competences to make contributions towards organizational performance. Smith (2015) also claimed that employee's training brings about motivation and ensures that employees are productive and innovative. He further argued that training makes more sense if, well trained employees were willing and capable of taking control over their jobs, needs minimum supervision with free management for other tasks. Thus, employees who really know their jobs, complain less and were highly motivated thus improving their relationship with the management.

\subsection{Impact of Training and Development}

$T \& D$ activities enhanced job performance and positive changes such as acquisition of new skills which serves as a track record for job performance. It was further found by Barber (2004) cited in Makafui (2014) that T\&D led to great innovative initiative and tacit skills. Robertson, Cooper, Sarkar \& Curran (2015) indicated that training affects change in employee skills through a change in employee's knowledge structures or mental models. Training may also impact employee's strategic knowledge which is known as the time to which employees can apply a specific knowledge or skill, thus training cannot only affect declaration and procedural knowledge only (Kozlowski, 2015). According to Moore (2013) training can also have an impact on employee's culture where it allows employees to adjust and work in different cultural environments.

Several researchers (Garcia, 2015; Amadi, 2014) in HRM have also indicated the impact of training and development on organizational performance. Further, Amadi (2014) indicated that T\&D has a positive impact on both employees' motivations and performance which promotes the need for continuous training. Garcia (2015) found that organizational training polices suggested that T\&D programs focused on human capital development were directly related to employee, customer, and shareholder's satisfaction as well as an objective measure of organizational performance. Riding on the advantages as T\&D endeavors in numerous organizations proceed to extend and develop, there has been a greater than ever pressure to show the results of training. It is very important to sufficiently demonstrate and communicate how training and development efforts hugely contributes to the effectiveness of an organization.

\subsection{The Significance of Employee Performance on Organizational Performance}

T\&D are one of the concepts that make employees more competent and more effective. According to Wright \& Geroy (2001), the level of employee competence is changed positively through effective training programs. Training programs are also used by managers to address some of the employee's needs. Effective training programs help employees to gain new technology that will help them to perform their duties and at the same time gain full 
command on the competences and skills required to perform that job with few errors and mistakes (Samwel, 2018). Employee's capabilities are enhanced through training which helps the organization achieve its performance with skills and qualified workforce.

Furthermore, T\&D have been recognized as one of the important catalysts which improve organizational productivity and the bottom line. According to Konings and Vanormelingen (2009) T\&D is an important tool that is highly effective when an organization wants to be successful and to achieve its objectives, resulting in higher productivity. In a related study by Bartel (2000) explained that employee training, employee productivity had a correlation on an organizational performance. This means that training and organizational performance had a positive relationship.

According to Samwel, (2018) the concept of employee learning through T\&D is assumed to be one of the key factors which increase employee performance and at the same time achieve organizational goals and influencing the performance of the organization. It is also alluded by Kauffman (2010) that, in the long run, companies which are embracing training and development practices are capable and able to retain their employees, customers, clients, stakeholders and shareholders. He further argued that when it comes to the improvement of employee retention, it is best to use the grass roots employee involvement programs like training in the organizations.

\subsection{Relationship Between Training and Development to Employees’ Performance}

Various studies on T\&D depicted that there was a strong relationship that is positive between human resources management practices and organizational performance (Elnaga \& Imran, 2013). According to Guest (1997) cited in Elnaga and Imran (2013) noted that T\&D programs is one of the critical philosophies in the practice of HRM as it has a positive effect on the quality of skills, knowledge, and capabilities which therefor results in better performance of employees on their jobs. The organizational performance is thus improved by the relation of the two concepts. Farooq \& Aslam (2011) conducted a study in which they investigated the relationship between employee training and employee performance, their results depicted a positive correlation relationship between training and employee performance as $r=233$. Therefore, the researcher can anticipate from this finding that it is not workable for the organization to obtain higher returns without using its human capital.

Moreover, this can only happen when an organization can meet its employees work related needs in a convenient form. T\&D is the main methods for recognizing the denied need of employees and after that building their required ability level, so they may perform well to accomplish organizational objectives.

Additionally, a study conducted by Sultana et al, (2012) in the Telecom sector of Pakistan has indicated that the $\mathrm{R}^{2}$ as 501 which depicts that, $50.1 \%$ of the variation in employee's performance is brought by in by T\&D programs. Furthermore, it has shown that T\&D is a good indicator of employee performance for it showed a T-Value of 8.58. Harrison (2000) indicated that learning through $\mathrm{T} \& \mathrm{D}$ influences the organizational performance by better employee performance, and it is alleged to be a key component in the accomplishment of 
organizational objectives. However, the implementation of training and development programs as an answer to cover performance concerns like improving working standards and actual performance is an effective way of improving employee performance (Elnaga \& Imran, 2013).

In another study by Sandamali, Dinithi Padmasiri, Mahalekamge and Mendis (2018) conducted quantitative and a cross-sectional survey has proved that there is a strong positive relationship between the T\&D and the executive level employees' performance in the Apparel industry in Sri Lanka. However, organizations should build a correct and logically substantial mechanism to select employees who participate in the training program (Sandamali et al., 2018). A similar sentiment was expressed by Sendawula, Kimuli, Bananuka and Muganga (2018) who used both cross sectional and correlational to investigate the contribution of training and employee engagement on employee performance in Uganda's health sector. Based on their findings, there is a positive association between (1) training and employee performance and (2) employee engagement and employee performance. Furthermore, the study indicates that there is a partial mediation whereby employee engagement mediates the relationship between training and employee performance (Sendawula et al., 2018).

Additionally, Imran and Tanveer (2015) study on the impact of training and development on employees' performance in the Banks of Pakistan used the descriptive and quite explanatory. Major findings were that most of the employees are clear on the fact that T\&D had a positive impact on their knowledge, work quality and quantity, functional skills, and their motivation and loyalty. All these is linked to their performance. Thus, the study concluded that T\&D had positive impact on employees' performance in the banks of Pakistan. Sanyal and Hisam (2016) studied the impact of training and development practices on the employee performance in the select Omani Public and Private sector banking organizations. The study adopted a descriptive research design with sample size of 300. The findings revealed that $T \& D$ practices have a positive influence on employee performance in the Omani Banking Industry. Further, Nassazi, (2013) evaluated the effects of training on employee performance, using the telecommunication industry in Uganda as case study. The study used qualitative research approach distributed amongst 120 respondents. Based on the results obtained indicated that training have a clear effect on the performance of employees.

Finally, many scholars indeed positively agree that there is a relationship between training and development to employee' performance. The literature is relevant to this study because it will assist in comparing the relationship between training and development using Namibia Defence Force as a case study.

\subsection{Conceptual Framework}

This study employed a conceptual framework using two training evaluation models; Kirkpatrick's four levels of evaluation training and Brinkerhoff's Six Stage Evaluation Mode to look at the relationship between training and development and employees' performance. These models fit well with this study as the focus was on the activities of training and development and the impact it has on employee's performance in the public sector. Pieters (2014) explained that there is reciprocal relationship between arrows from Block A, B, C and $\mathrm{D}$ directed to Block E. Thus, any negativity in to Block A, B, C or D influences the 
employee's performance and organization.

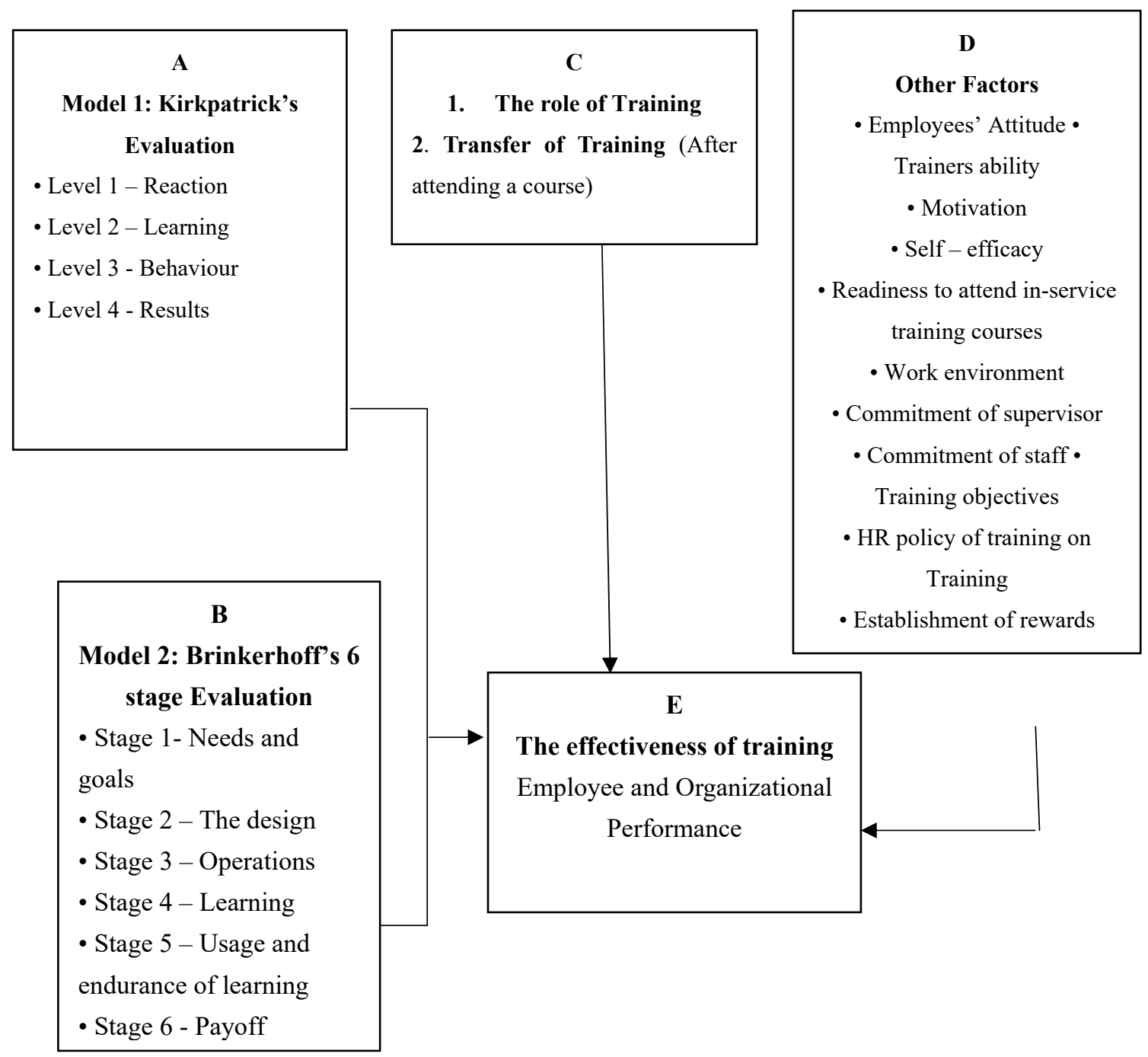

Figure 1. Conceptual Framework

Adapted from Pieters (2014, p.14).

\section{Research Methodology}

\subsection{Design of the Study}

There are two approaches of research methodologies namely: quantitative and qualitative methodology. Qualitative research is known to uncover fundamental causes, sentiments, beliefs, incentives, trends opinions and thoughts, which can be used for the development of hypotheses for potential quantitative study (Singleton \& Straits, 2010). According to Bhattacherjee (2012), "behaviours, attitudes and perceptions are quantified through the generation of numerical data and findings from a larger population sample are generalized". The study employed the quantitative research which revolves around positivists' philosophy and tends to view that only factual knowledge gained through observation, including measurement were trustworthy (Smith, 2010). This approach was chosen to guide the present 
study because of its relevance to analyze theory through statistical data collection and to prove or disprove the hypotheses (Leedy \& Omrod, 2010).

\subsection{Data Sources and Collection Methods}

Primary data was collected through self-administered questionnaire consisting of closed-ended questions fixed on 5-Likert scale for measurement. The closed-ended response to questions was best suited to have easier coding and quantitative analysis.

\subsection{Target Population, Sample Size and Sampling Technique}

Raderbauer (2011) defines population as "the total collection of elements about which inferences are to be made." The target population for this study was supposed to consist of 500 employees from Military School (MS) and Namibia Command and Staff College (NCSC) in Okahandja to represent general view of the organization. Brynard, Hanekom and Brynard (2014) stated that the size of the sample should be enough to reflect the characteristics of the population (e.g., 20\% x 500 = 100). Based on these, the selection ensured that all elements in the organizational structure namely low, middle, and senior management were represented to add more value to the study. Therefore, the sample size of this study comprised of 100 employees $(\mathrm{N}=100)$ divided in proportions of 25\% -senior management (Colonel-Brigadier General), 25\% -middle management (Lieutenant Colonel-Major), 25\% - junior management (Lieutenant-Warrant Officer Class 2) and 25\% - other ranks (Private-Staff Sergeant). These people were selected to have rich information related to the study.

\subsection{Validity of the Research Instrument}

Validity refers to the extent to which an instrument measures what it is intended to measure (Leedy et al, 2010). Four different types of validity were observed in this study namely: face validity, content validity, criterion validity and concurrent validity. The researcher asked colleagues and individuals from the target population to comment on the relevance, balance, and adequacy of the questionnaire in terms of research objectives.

Furthermore, the researcher sought professional opinion in the field to confirm the adequacy of the questionnaire. During the pilot study, the researcher checked the level of responses to items on the questionnaire to ensure that it was parallel to other facets of the respondent's overall behavior.

\subsection{Reliability of the Research Instrument}

Reliability refers to the consistency with which a measuring instrument yields certain results over a period (Leedy et al., 2010). Three types of reliability were used for different purposes: inter-rater consistency, parallel forms reliability and test-retest reliability. The researcher had two different raters to rate the behaviors and then determined the degree of agreement between them. Also, the researcher gave different forms of the same test to the same group of participants to check correlation with each other. The researcher aimed at using the re-test method which the same test is given to the same people after some period. The reliability of the test was then estimated by examining the consistency of the responses between the two tests. 


\section{Macrothink}

\subsection{Delimitation of the Study}

This study focused only on Military School (MS) and Namibia Command and Staff College (NCSC) employees based in Okahandja. Therefore, the findings of this study cannot be generalized to the whole NDF in the country.

\subsection{Method of Data Analysis}

Quantitative data obtained from the questionnaire was coded and analysed using Statistical Package for the Social Sciences (SPSS) version 22 mainly frequency distribution and pie charts to present findings.

\section{Data Analysis and Interpretation of the Results}

\subsection{Analysis of the Response Rate}

A sample of 100 employees were selected from a total of 500 employees from Military School (MS) and Namibia Command and Staff College (NCSC) in Okahandja. In this regard, a total of 100 questionnaires were issued and distributed to the employees to gather the necessary data for the study. The respondents were given maximum one month to fill the questionnaire with the aim to achieve high response rate. Table 1 shows the total response rate of respondents. From the 100 questionnaires that was distributed, 87 responses were received back. The variance of 13 questionnaires were not returned due to unknown reasons. Some respondents were given the questionnaires and proceeded to their annual leave and thus did not return the questionnaires.

Table 1. Response rate

\begin{tabular}{|l|c|c|}
\hline Target population & N=100 & Valid percent \\
\hline Senior management & 5 & 5.7 \\
\hline Middle management & 13 & 14.9 \\
\hline Junior management & 28 & 32.2 \\
\hline $\begin{array}{l}\text { Other ranks (Private-staff } \\
\text { sergeants) }\end{array}$ & 41 & 47.1 \\
\hline Total respondents & 87 & 100 \\
\hline
\end{tabular}

Source: Researcher's own Computations from the questionnaire

\subsection{Biographical Characteristics of the Respondents}

Figure 1 and Table 2 represents the gender distribution of the respondents who completed the questionnaires. The findings indicate higher response rate from males' employees with $(57.5 \%)$ and the minority were females with $42.5 \%$ representation. These shows that the NDF is a male dominated industry, but the female contribution was reasonable due to the nature of the study. 


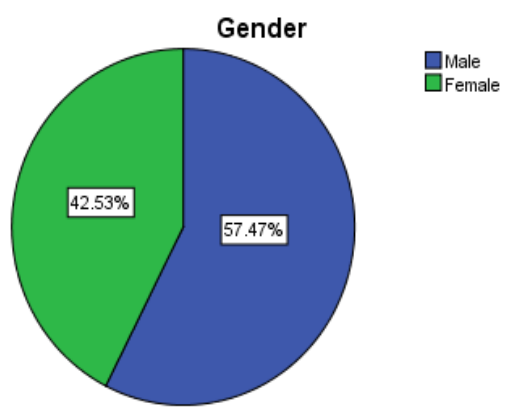

Figure 1. Gender of the respondents

Source: Researcher's own Computations from the questionnaire

Table 2. Gender of the respondents

\begin{tabular}{|l|l|c|c|c|c|}
\hline & & Frequency & Percent & Valid Percent & Cumulative Percent \\
\hline \multirow{2}{*}{ Valid } & Male & 50 & 57.5 & 57.5 & 57.5 \\
\cline { 2 - 6 } & Female & 37 & 42.5 & 42.5 & 100.0 \\
\hline
\end{tabular}

Source: Researcher's own Computations from the questionnaire

Figure 2 and Table 3 shows the age group distribution of respondents. The result show that most of the employees who participated in the study $43.7 \%$ were in the age group of $31-40$ years old whilst $29.9 \%$ in the age group of $18-30$ years old.

The results also showed that $16.1 \%$ of the respondents were between $41-50$ years old and the least was $10.3 \%$ in the age group of 51 years and above. Thus, the findings indicate that the NDF was highly occupied by employees who are young and still energetic with the zeal and strength to move the Ministry forward. In summary, the results were in support of the Human Resource Manpower statistics (2018) which revealed that the highest number of employees were between the age group of 31-40.

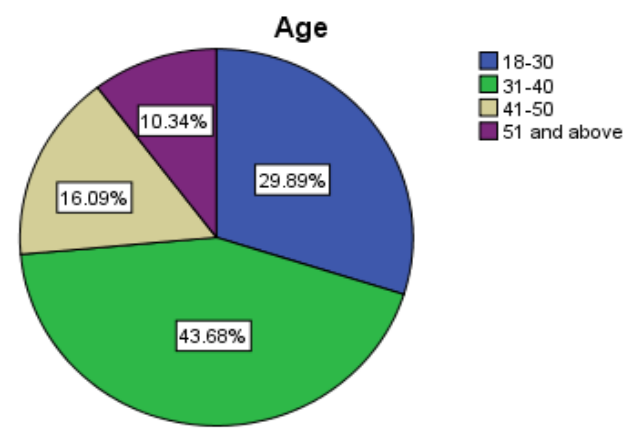

Figure 2. Age of the respondents

Source: Researcher's own Computations from the questionnaire 
Table 3. Age of the respondents

\begin{tabular}{|l|l|c|c|c|c|}
\hline & Frequency & Percent & Valid Percent & Cumulative Percent \\
\hline Valid & $\mathbf{1 8 - 3 0}$ & 26 & 29.9 & 29.9 & 29.9 \\
\hline & $\mathbf{3 1 - 4 0}$ & 38 & 43.7 & 43.7 & 73.6 \\
\hline $\mathbf{4 1 - 5 0}$ & 14 & 16.1 & 16.1 & 89.7 \\
\hline $\mathbf{5 1}$ and above & 9 & 10.3 & 10.3 & 100.0 \\
\hline
\end{tabular}

Source: Researcher's own Computations from the questionnaire

Figure 3 and Table 4 shows the educational qualifications that were held by employees in the NDF. The highest percentage of employees (56.3\%) pointed only to had secondary certificates followed by $29.9 \%$ who had diplomas. The other $6.9 \%$ pointed out that to have primary certificates and those with degrees were only $6.9 \%$. Therefore, it was established that the NDF was dominated by employees who do not proceed much further in terms of personal development. According to the NDF Recruitment Policy (2017), the minimum qualification results for job entry usually is Grade 12 and perhaps that was the reason for majority of employees to had secondary certificates.

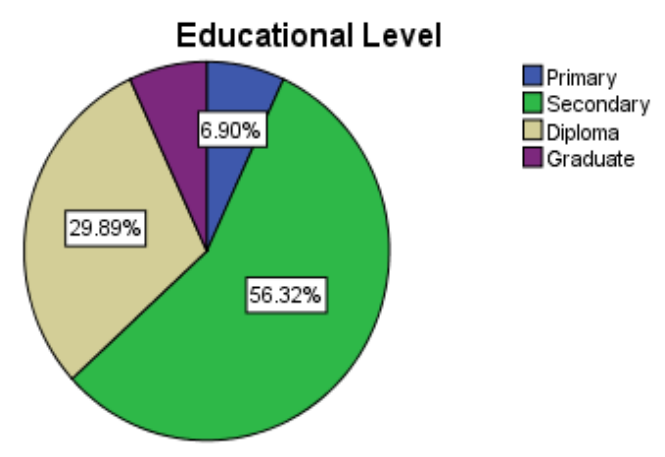

Figure 3. Educational Level

Source: Researcher's own Computations from the questionnaire

Table 4. Educational level

\begin{tabular}{|l|l|c|c|c|c|}
\hline & Frequency & Percent & Valid Percent & Cumulative Percent \\
\hline \multirow{2}{*}{ Valid } & Primary & 6 & 6.9 & 6.9 & 6.9 \\
\cline { 2 - 6 } & Secondary & 49 & 56.3 & 56.3 & 63.2 \\
\hline & Diploma & 26 & 29.9 & 29.9 & 93.1 \\
\hline & Graduate & 6 & 6.9 & 6.9 & 100.0 \\
\hline
\end{tabular}

Source: Researcher's own Computations from the questionnaire

Figure 4 and Table 5 shows the number of years the respondents have been working in the NDF. The result indicates that most of employees (26.4\%) have been working in the NDF for 


\section{Macrothink}

International Journal of Human Resource Studies

ISSN 2162-3058 2020, Vol. 10, No. 3

a period of 1-5 years, followed by $24.1 \%$ who worked for a period between $6-10$ years and 16-20 years, respectively. The last group of employees' (12.6\%) worked for 11-15 years and 21 years and above.

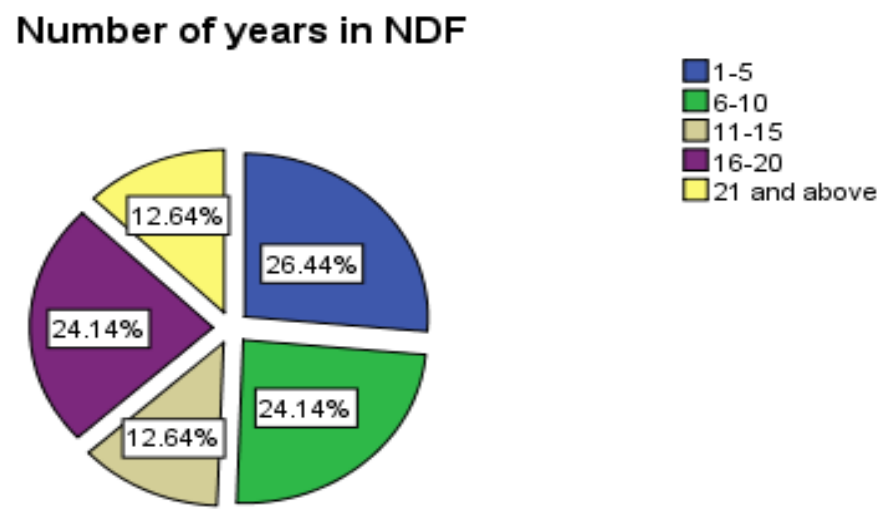

Figure 4. Number of years as an NDF employees

Source: Researcher's own Computations from the questionnaire

Table 5. Number of years as an NDF employees

\begin{tabular}{|c|c|c|c|c|c|}
\hline & & Frequency & Percent & Valid Percent & Cumulative Percent \\
\hline \multirow{6}{*}{ Valid } & $1-5$ & 23 & 26.4 & 26.4 & 26.4 \\
\hline & $6-10$ & 21 & 24.1 & 24.1 & 50.6 \\
\hline & $11-15$ & 11 & 12.6 & 12.6 & 63.2 \\
\hline & $16-20$ & 21 & 24.1 & 24.1 & 87.4 \\
\hline & 21 and above & 11 & 12.6 & 12.6 & 100.0 \\
\hline & Total & 87 & 100.0 & 100.0 & \\
\hline
\end{tabular}

Source: Researcher's own Computations from the questionnaire

Table 6 below shows the workplace levels or positions occupied by the respondents. The employees were categorized into four levels namely, senior management, middle management, junior management, and other ranks. It was highlighted that the senior management had $5.7 \%$, the middle management had $14.9 \%$ representation, the junior management had 32.2\% representation, and the other ranks (Private-Staff Sergeant) had $47.1 \%$ representation. 
Table 6. Category of positions

\begin{tabular}{|c|c|c|c|c|c|}
\hline & & Frequency & Percent & Valid Percent & $\begin{array}{c}\text { Cumulative } \\
\text { Percent }\end{array}$ \\
\hline \multirow[t]{5}{*}{ Valid } & $\begin{array}{l}\text { Senior management } \\
\text { (Colonel-Brigadier } \\
\text { General) }\end{array}$ & 5 & 5.7 & 5.7 & 5.7 \\
\hline & $\begin{array}{l}\text { Middle management } \\
\text { (Lieutenant } \\
\text { Colonel-Major) }\end{array}$ & 13 & 14.9 & 14.9 & 20.7 \\
\hline & $\begin{array}{l}\text { Junior management } \\
\text { (Lieutenant-Warrant } \\
\text { Class 2) }\end{array}$ & 28 & 32.2 & 32.2 & 52.9 \\
\hline & $\begin{array}{l}\text { Other ranks (Private- } \\
\text { Staff Sergeant) }\end{array}$ & 41 & 47.1 & 47.1 & 100.0 \\
\hline & Total & 87 & 100.0 & 100.0 & \\
\hline
\end{tabular}

Source: Researcher's own Computations from the questionnaire

\subsection{Reliability Assessment of the Questionnaires}

The Cronbach's Alpha value for all the independent scales is shown below in Table 7. Each question and scale in the questionnaire were measured to ensure that all reliable results are outlined or scored. The questionnaire obtained a Cronbach Alpha value of 0.708 which was an acceptable value of reliability. The table below represents the measure of internal consistency, that is how closely or related a set of items were as a group. The Alpha coefficient for the 22 items is 0.708 , suggesting that the items had relatively high internal consistence.

Table 7. Reliability statistics

\begin{tabular}{|c|c|c|}
\hline \multicolumn{3}{|c|}{ Reliability Statistics } \\
\hline Cronbach's Alpha & $\begin{array}{c}\text { Cronbach's Alpha Based on Standardized } \\
\text { Items }\end{array}$ & $\mathrm{N}$ of Items \\
\hline 0.708 & 0.692 & 0.22 \\
\hline
\end{tabular}

Source: Researcher's own Computations from the questionnaire

\subsection{Training Attendance Frequency}

The below Figure 5 and Table 8 shows the number of times the respondents go for trainings each year. The results revealed that $60.9 \%$ alleged not to go for any training whilst $25.3 \%$ did go for training once in a year. The remaining $8 \%$ said to go twice in a year, $4.6 \%$ thrice in a year and only $1.1 \%$ go for training 4 times in a year. In summary, it was established that most employees do not go for training each year. 


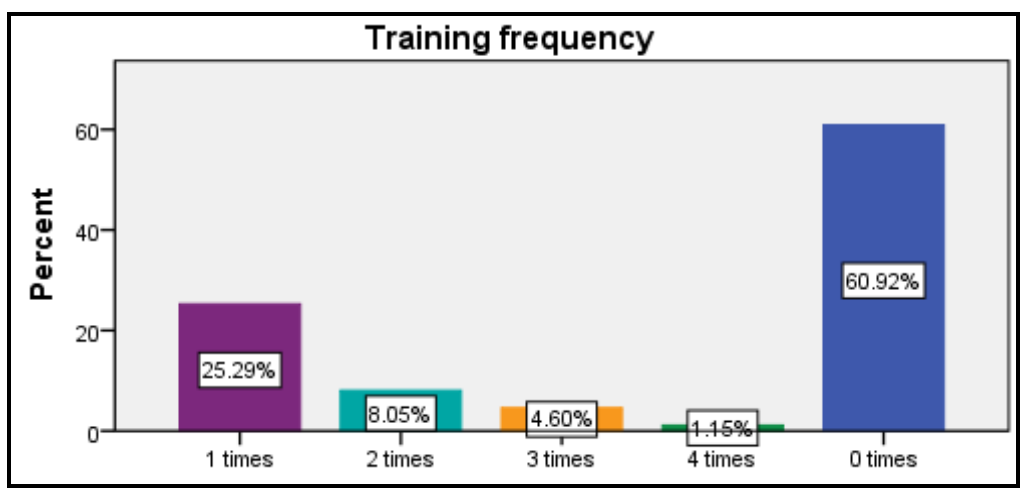

Figure 5. Training Frequency

Source: Researcher's own Computations from the questionnaire

Table 8. Training Frequency

\begin{tabular}{|l|l|r|r|r|r|}
\hline & Frequency & Percent & Valid Percent & Cumulative Percent \\
\hline Valid & $\mathbf{1}$ time & 22 & 25.3 & 25.3 & 25.3 \\
\hline $\mathbf{2}$ times & 7 & 8.0 & 8.0 & 33.3 \\
\hline $\mathbf{3}$ times & 4 & 4.6 & 4.6 & 37.9 \\
\hline $\mathbf{4}$ times & 1 & 1.1 & 1.1 & 39.1 \\
\hline $\mathbf{0}$ time & 53 & 60.9 & 60.9 & 100.0 \\
\hline & Total & 87 & 100.0 & 100.0 & \\
\hline
\end{tabular}

Source: Researcher's own Computations from the questionnaire

\subsection{T\&D Changing Employee Skills, Knowledge, and Attitude}

Figure 6 and Table 8 represents how training and development was changing the employee's skills, knowledge and attitude. The results showed that most of respondents (56.3\%) strongly agree that training and development has changed their skills, knowledge, and attitude. On the other hand, 33.3\% agree, whilst 5.7\% disagree and $4.6 \%$ were not sure. The study also found out that no one seems to have strongly disagreed with the notion. This however indicates that, most employees who undergo training had changed in terms skills, knowledge, and attitude. This was in line with Shaheen, Naqvi \& Khan (2013) that training, and development improves employee knowledge and information in work and increases the advantage to network for efficacy and performance of employees. Further, the results were also in line with other studies by Nassazi (2013) that, training and development positively influence employee skills, capabilities and competences which allows for better performance in their jobs. 


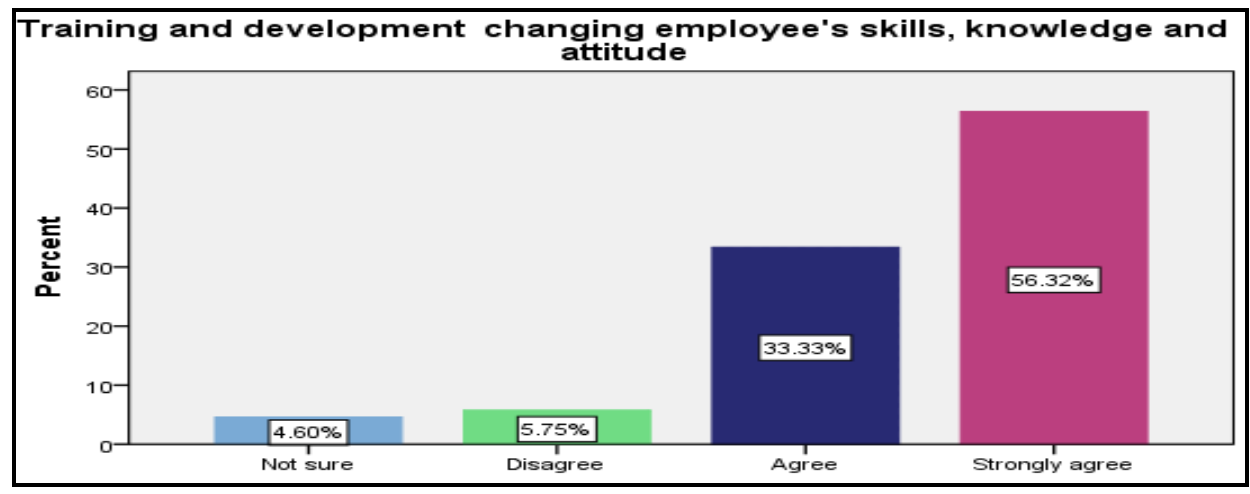

Figure 6. T\&D changing employee skills, knowledge, and attitude

Source: Researcher's own Computations from the questionnaire

Table 8. T\&D changing employee skills, knowledge, and attitude

\begin{tabular}{|c|c|c|c|c|c|}
\hline & & Frequency & Percent & Valid Percent & $\begin{array}{c}\text { Cumulative } \\
\text { Percent }\end{array}$ \\
\hline \multirow[t]{5}{*}{ Valid } & Not sure & 4 & 4.6 & 4.6 & 4.6 \\
\hline & Disagree & 5 & 5.7 & 5.7 & 10.3 \\
\hline & Agree & 29 & 33.3 & 33.3 & 43.7 \\
\hline & Strongly agree & 49 & 56.3 & 56.3 & 100.0 \\
\hline & Total & 87 & 100.0 & 100.0 & \\
\hline
\end{tabular}

Source: Researcher's own Computations from the questionnaire

\subsection{T\&D Increases Job Satisfaction}

From this question, the study aimed to find out if the training and development programs had or increase job satisfaction amongst employees. Table 9 and Figure 7 illustrates $71.3 \%$ of the respondents agreed that the training and development program has changed their job satisfaction, $24.1 \%$ of the respondents strongly agreed, $2.3 \%$ disagreed and $2.3 \%$ were not sure, respectively. The finding was supported by Adesola, Oyeniyi \& Adeyemi (2013) that training, and development programmes have been acknowledged as one of the managerial tools that enhances employee satisfaction worldwide. Burgard \& Gorlitz (2011) also argued that training has the capability of improving the working environment, encourages interactions amongst employees or some employees enjoys learning as such discovers and experiences new ideas. Similarly, training also contributes to job satisfaction doing new things and moving away from repeated daily routines. 


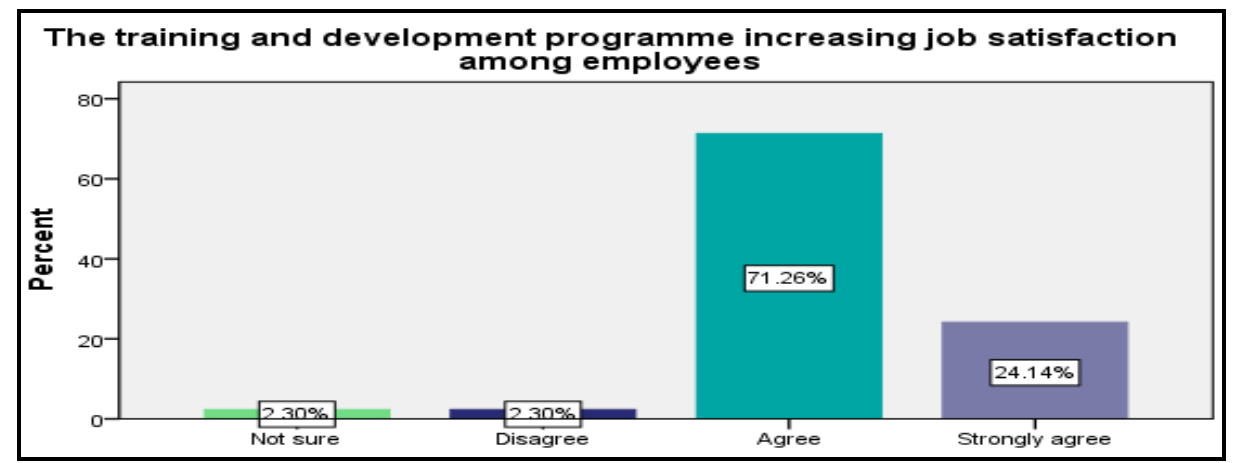

Figure 7. T\&D Increases Job Satisfaction

Source: Researcher's own Computations from the questionnaire

Table 9. T\&D Increases Job Satisfaction

\begin{tabular}{|l|l|r|r|r|r|}
\hline & & Frequency & Percent & Valid Percent & Cumulative Percent \\
\hline \multirow{2}{*}{ Valid } & Not sure & 2 & 2.3 & 2.3 & 2.3 \\
\cline { 2 - 6 } & Disagree & 2 & 2.3 & 2.3 & 4.6 \\
\cline { 2 - 6 } & Agree & 62 & 71.3 & 71.3 & 75.9 \\
\cline { 2 - 6 } & Strongly agree & 21 & 24.1 & 24.1 & 100.0 \\
\cline { 2 - 6 } & Total & 87 & 100.0 & 100.0 & \\
\hline
\end{tabular}

Source: Researcher's own Computations from the questionnaire

\subsection{Intellectual Growth of the NDF Departments in Relation to Training}

Figure 8 and Table 10 below shows the degree of how training was essential for intellectual growth in the NDF departments. It was agreed (56.3\%) by most of the respondents whilst $34.5 \%$ strongly agreed that training was essential for intellectual growth in the NDF departments. On the other hand, $2.3 \%$ disagreed and only $6.9 \%$ were not sure.

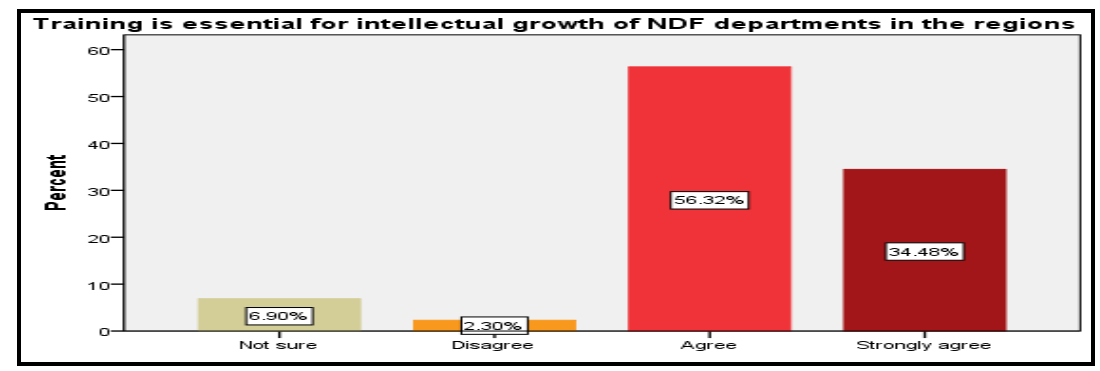

Figure 8. Intellectual Growth of NDF Departments in Relation to Training

Source: Researcher's own Computations from the questionnaire 


\section{Macrothink}

International Journal of Human Resource Studies

Table 10. Intellectual Growth of NDF Departments in Relation to Training

\begin{tabular}{|l|l|r|r|r|r|}
\hline & Frequency & Percent & Valid Percent & Cumulative Percent \\
\hline Valid & Not sure & 6 & 6.9 & 6.9 & 6.9 \\
\cline { 2 - 6 } & Disagree & 2 & 2.3 & 2.3 & 9.2 \\
\hline Agree & 49 & 56.3 & 56.3 & 65.5 \\
\hline Strongly & 30 & 34.5 & 34.5 & 100.0 \\
\hline & & & & \\
\hline & agree & & 100.0 & 100.0 & \\
\hline
\end{tabular}

Source: Researcher's own Computations from the questionnaire

\subsection{Effects of T\&D on Employees' Performance}

In addition, the respondents were also asked how training and development had impacted their performance. Most respondents 45\% agree and 37.9\% strongly disagree that training and development had positively impacted them to perform better. On the other side, $4.6 \%$ disagree and only $11.5 \%$ were not sure. The findings support Amin et al., (2013) that training, and development leads to better performance and the benefits span from team performance and individual performance to economic prosperity of a country. Likewise, Smith (2015) pointed that employee' training brings about motivation and makes employees more productive and innovative. He further reiterated that training makes more sense in that, well trained employees could take control over their jobs with minimum supervision.

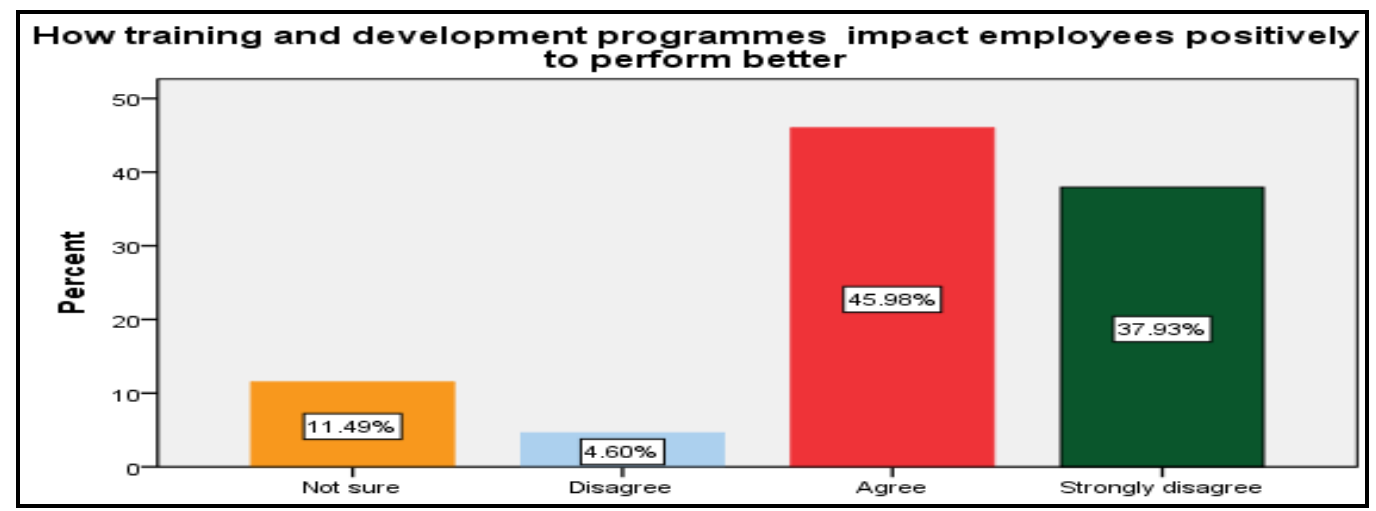

Figure 9. Effects of T\&D on employees' performance

Source: Researcher's own Computations from the questionnaire 


\section{Macrothink}

Table 11. Effects of T\&D on employees' performance

\begin{tabular}{|l|l|r|r|r|r|}
\hline & Frequency & Percent & Valid Percent & Cumulative Percent \\
\hline \multirow{2}{*}{ Valid } & Not sure & 10 & 11.5 & 11.5 & 11.5 \\
\hline Disagree & 4 & 4.6 & 4.6 & 16.1 \\
\hline Agree & 40 & 46.0 & 46.0 & 62.1 \\
\hline Strongly & 33 & 37.9 & 37.9 & 100.0 \\
\hline & & & & \\
\hline & disagree & 87 & 100.0 & 100.0 & \\
\hline
\end{tabular}

Source: Researcher's own Computations from the questionnaire

\subsection{Improve productivity}

As a follow up, Figure 10 and Table 12 shows the respondents thoughts in terms of production being improved through training and development programs. The results indicate that $88.5 \%$ fully agreeing that production has improved since the introduction of employee' training and development programs whilst $11.5 \%$ did not agree. According to Nassazi (2013) training and development plays a crucial role in building organizations, improving performance and as well increasing productivity. Therefore, training and development have been recognized as one of the important catalysts which improves organizational productivity and competitive advantage. Furthermore, training and development is an important tool that is highly effective when an organization wants to be successful and achieve its objectives, resulting in higher productivity (Konings \& Vanormelingen, 2009).

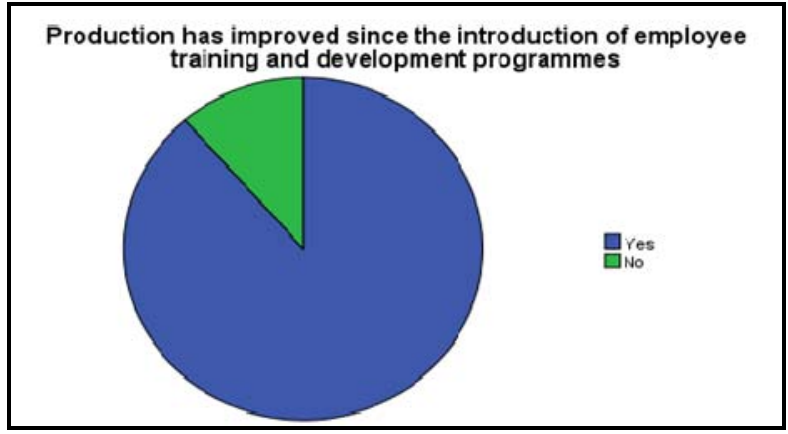

Figure 10. Improve productivity

Source: Researcher's own Computations from the questionnaire

Table 12. Improve productivity

\begin{tabular}{|l|l|r|r|r|r|}
\hline & & Frequency & Percent & Valid Percent & Cumulative Percent \\
\hline \multirow{2}{*}{ Valid } & Yes & 77 & 88.5 & 88.5 & 88.5 \\
\cline { 2 - 6 } & No & 10 & 11.5 & 11.5 & 100.0 \\
\hline & Total & 87 & 100.0 & 100.0 & \\
\hline
\end{tabular}

Source: Researcher's own Computations from the questionnaire 


\section{Macrothink \\ International Journal of Human Resource Studies \\ ISSN 2162-3058 \\ 2020, Vol. 10, No. 3}

\subsection{Significance of Employee Performance to an Organization}

The frequency bar chart Figure 11 and Table 13 shows the respondents thoughts in terms of the NDF investing in training programs to hence better performance. The results show that $65.5 \%$ of the respondents strongly agreed that the NDF should invest more in training programs to enhance better performance. On the other hand, $26.4 \%$ agreed whilst $6.9 \%$ were not sure and $1.1 \%$ strongly disagreed. In summary, the results highly indicate that the employees do regard the importance of training, thus would want to see the NDF invests more in T\&D.

The results was in line with the views of Motlokoa, Sekantsi \& Monyolo (2017) that it is imperative to invest in continuous training and development in order to improve employees' skills, knowledge and capabilities required for the achievement of organizational goals. According to Chinomnso (2014) many organizations had realized that the success of their companies lies in the employee' development. Therefore, these organizations allocate more resources for continuous training to achieve a competitive position.

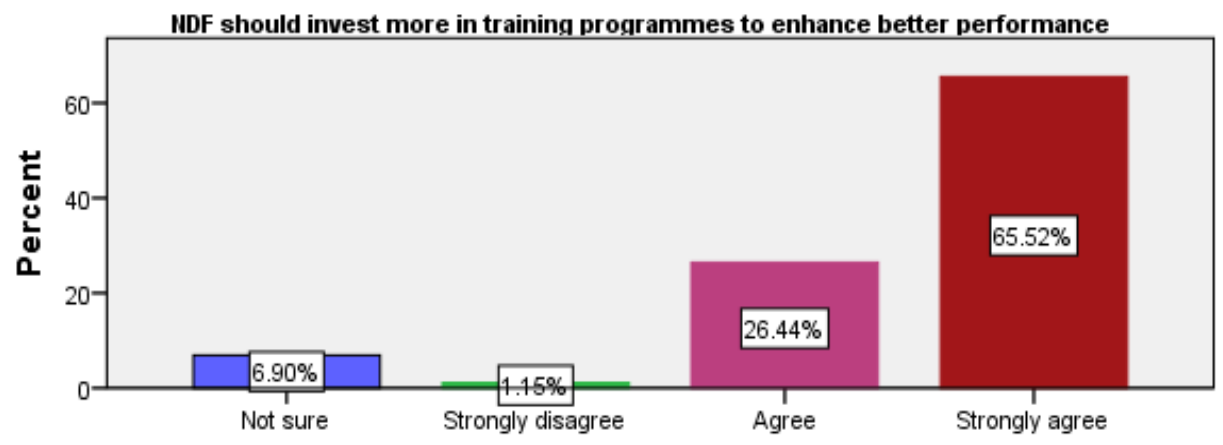

Figure 11. Significance of Employee Performance to an Organization

Source: Researcher's own Computations from the questionnaire

Table 13. Significance of Employee Performance to an Organization

\begin{tabular}{|l|l|r|r|r|r|}
\hline & Frequency & Percent & Valid Percent & Cumulative Percent \\
\hline \multirow{2}{*}{ Valid } & Not sure & 6 & 6.9 & 6.9 & 6.9 \\
\cline { 2 - 5 } & Strongly & 1 & 1.1 & 1.1 & 8.0 \\
\hline & disagree & & & & 34.5 \\
\hline & Agree & 23 & 26.4 & 26.4 & 100.0 \\
\hline & Strongly agree & 57 & 65.5 & 65.5 & 100.0 \\
\hline
\end{tabular}

Source: Researcher's own Computations from the questionnaire

Change in Performance Amongst the Employees

Figure 12 and Table 14 shows the extent of change in performance amongst employees. From the responses, the majority (50.6\%) agreed, 36.8\% strongly agreed, 4.6 disagree whilst 3.4 


\section{Macrothink}

International Journal of Human Resource Studies

ISSN 2162-3058 2020, Vol. 10, No. 3

strongly disagreed and the last $4 \%$ were not sure. The results were consistent with Smith (2015) that training, and development improves team performance both in the long and short run. Thus, employees tend to work faster and share ideas from different perspective due to increase in knowledge, skills and capabilities derived from the training and development.

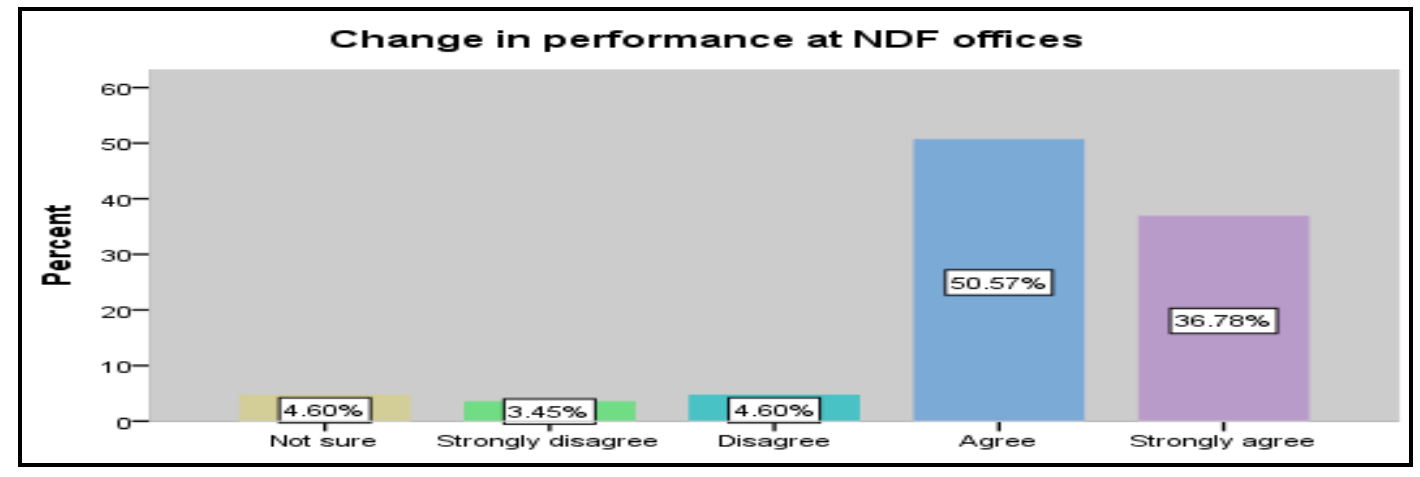

Figure 12. Change in Performance Amongst the Employees

Source: Researcher's own Computations from the questionnaire

Table 14. Change in Performance Amongst the Employees

\begin{tabular}{|l|l|r|r|r|r|}
\hline & Frequency & Percent & Valid Percent & Cumulative Percent \\
\hline Valid & Not sure & 4 & 4.6 & 4.6 & 4.6 \\
\hline $\begin{array}{l}\text { Strongly } \\
\text { disagree }\end{array}$ & 3 & 3.4 & 3.4 & 8.0 \\
\hline Disagree & & & & 12.6 \\
\hline Agree & 4 & 4.6 & 4.6 & 63.2 \\
\hline Strongly agree & 32 & 50.6 & 50.6 & 100.0 \\
\hline Total & 87 & 36.8 & 36.8 & \\
\hline
\end{tabular}

Source: Researcher's own Computations from the questionnaire

\subsection{Errors Recorded After the T\&D Programmes}

The respondents were also asked their thoughts on the rate of errors recorded ever since T\&D programs. From the responses showed in Figure 13 and Table 15, 42.5\% agreed whilst 17.2\% strongly agreed. On the other hand, 9.2\% disagreed and strongly disagreed respectively that less errors were recorded since taking part in the training and development programs. The last $21.8 \%$ respondents pointed out that they were not sure if less errors were being recorded. 


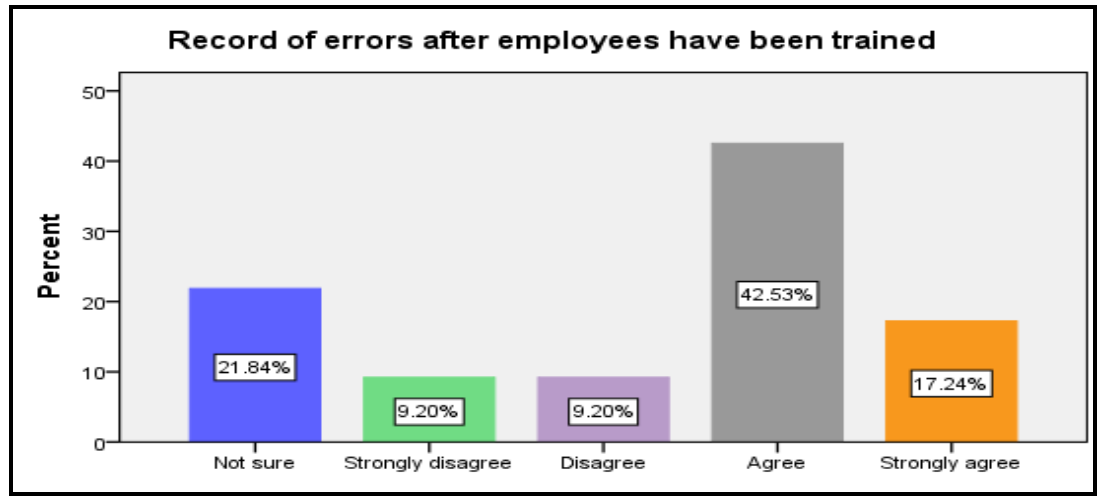

Figure 13. Errors Recorded After the T\&D Programmes

Source: Researcher's own Computations from the questionnaire

Table 15. Errors Recorded After the T\&D Programmes

\begin{tabular}{|l|r|r|r|r|r|}
\hline & Frequency & Percent & Valid Percent & Cumulative Percent \\
\hline Valid & Not sure & 19 & 21.8 & 21.8 & 21.8 \\
\hline $\begin{array}{l}\text { Strongly } \\
\text { disagree }\end{array}$ & 8 & 9.2 & 9.2 & 31.0 \\
\hline Disagree & & & & 40.2 \\
\hline Agree & 37 & 9.2 & 9.2 & 82.8 \\
\hline Strongly agree & 15 & 42.5 & 42.5 & 100.0 \\
\hline Total & 87 & 17.2 & 17.2 & \\
\hline
\end{tabular}

Source: Researcher's own Computations from the questionnaire

\subsection{T\&D in Relation to Client Satisfaction}

The study also examined T\&D in relation to client satisfaction. Table 16 and Figure 14 shows that $43 \%$ of the respondents agreed that employee training and development has increased client satisfaction within the NDF whilst $17.2 \%$ strongly agreed, 3\% disagreed, $5 \%$ strongly disagreed and the last 21\% were not sure. The results support Mthokozosi \& Clifford (2015) view that investment in employee training and development was geared towards enhancing employee retention, customer satisfaction and the creativity of new products and services. Training can also be viewed in many ways, the focus being to empower employees with knowledge that benefits the organization, customers, and employees (Samwel, 2018). 


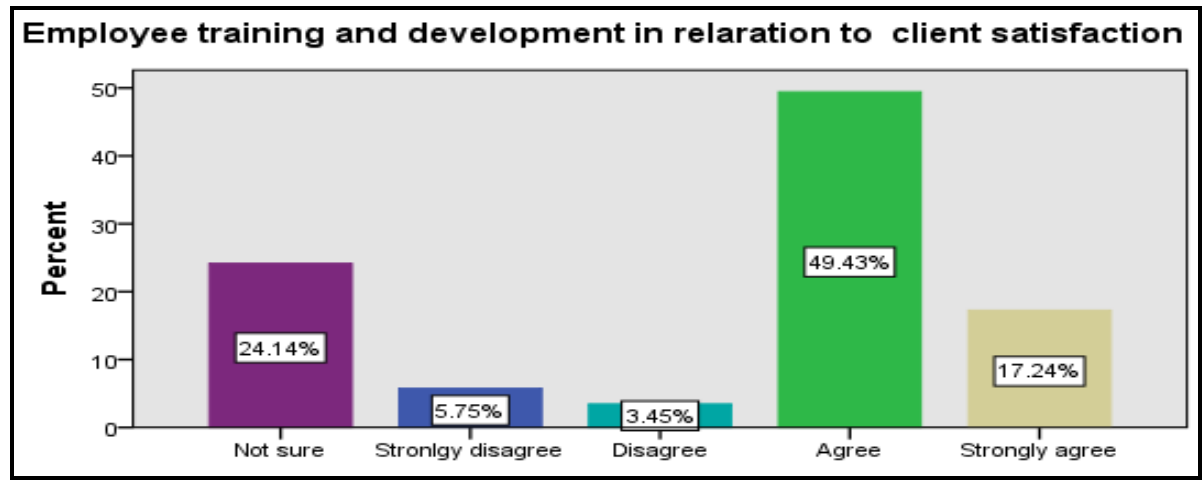

Figure 14. T\&D in Relation to Client Satisfaction

Source: Researcher's own Computations from the questionnaire

Table 16. T\&D in Relation to Client Satisfaction

\begin{tabular}{|l|l|r|r|r|r|}
\hline & Frequency & Percent & Valid Percent & Cumulative Percent \\
\hline Valid & Not sure & 21 & 24.1 & 24.1 & 24.1 \\
\hline Strongly disagree & 5 & 5.7 & 5.7 & 29.9 \\
\hline Disagree & 3 & 3.4 & 3.4 & 33.3 \\
\hline Agree & 43 & 49.4 & 49.4 & 82.8 \\
\hline Strongly agree & 15 & 17.2 & 17.2 & 100.0 \\
\hline Total & 87 & 100.0 & 100.0 & \\
\hline
\end{tabular}

Source: Researcher's own Computations from the questionnaire

\subsection{Impact of $T \& D$ on NDF Employees}

Figure 15 and Table 17 explored the perception of respondents with regards to how training and development programs helped the NDF officers in carrying out their duties. The results show that the majority $32.2 \%$ highlighted that T\&D programs had helped officers to carry out their duties effectively, $29.9 \%$ were excellent and $21.8 \%$ only better. One the other hand, $5.7 \%$ highlighted poor and $10.3 \%$ were not sure. The findings support Saeed \& Asghar (2012) that through training and development programs, employees were able to be assigned on different jobs and inspired to take individual creativities to apply those skills in their daily duties. In addition, the findings were in line with Amin et al. (2013) that employee was the real assets of an organization and if fully trained, they do their duties with full dedication an honor. 


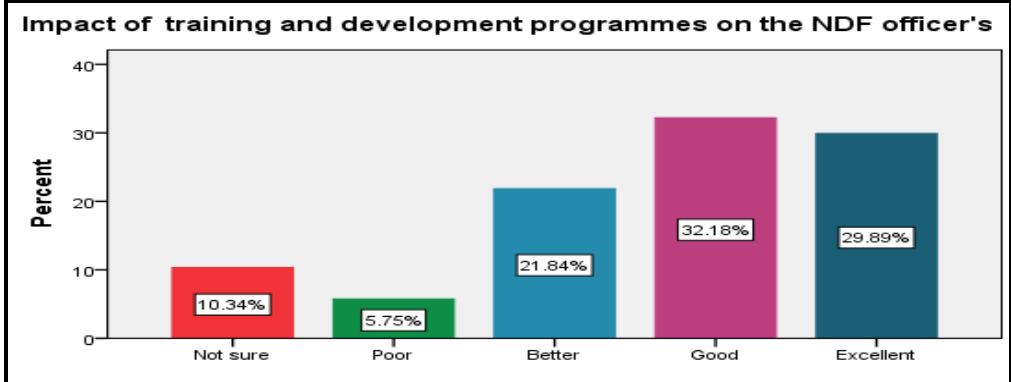

Figure 15. Impact of T \&D on NDF employees

Source: Researcher's own Computations from the questionnaire

Table 17. Impact of T \&D on NDF employees

\begin{tabular}{|l|l|r|r|r|r|}
\hline & Frequency & Percent & Valid Percent & Cumulative Percent \\
\hline Valid & Not sure & 9 & 10.3 & 10.3 & 10.3 \\
\cline { 2 - 6 } & Poor & 5 & 5.7 & 5.7 & 16.1 \\
\hline Better & 19 & 21.8 & 21.8 & 37.9 \\
\hline Good & 28 & 32.2 & 32.2 & 70.1 \\
\hline Excellent & 26 & 29.9 & 29.9 & 100.0 \\
\hline
\end{tabular}

Source: Researcher's own Computations from the questionnaire

\subsection{Relationship Between T\&D and Employee's Performance}

In this question, the study wanted to find out if there was any correlation between employee training and organizational performance. From the respondence in Table 18 and Figure 16 shows that the majority 55.2\% agreed that was positive relationship between T\&D and employee's performance and $19.5 \%$ highlighted that there was just a correlation. The other $4.6 \%$ disagreed, $6.9 \%$ strongly disagreed and the $13.8 \%$ were not sure. The findings are in consistent with Chinonmso (2014) that training, and development had a positive correlation to employees' performance.

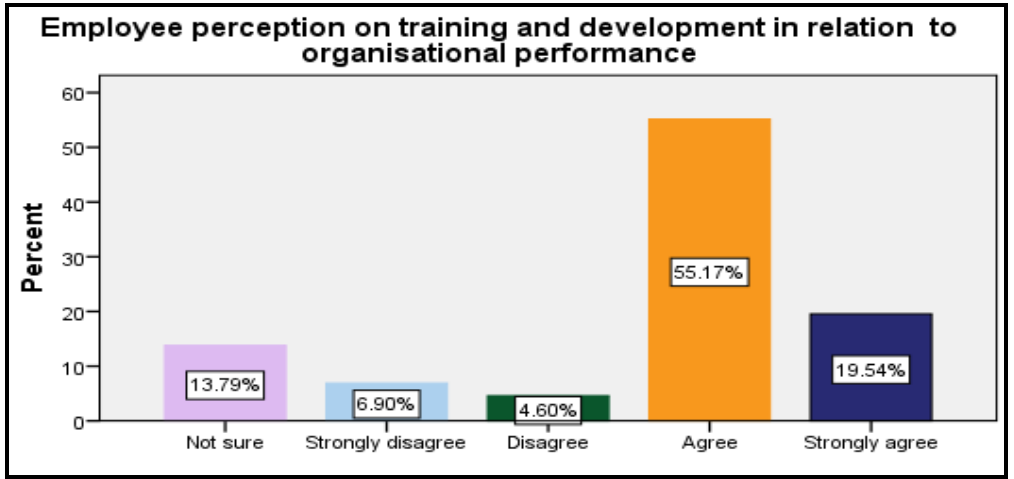

Figure 16. Relationship Between T\&D and Employee's Performance

Source: Researcher's own Computations from the questionnaire 


\section{Macrothink}

International Journal of Human Resource Studies

ISSN 2162-3058

2020, Vol. 10, No. 3

Table 18. Relationship Between T\&D and Employee's Performance

\begin{tabular}{|l|l|r|r|r|r|}
\hline & Frequency & Percent & Valid Percent & Cumulative Percent \\
\hline Valid & Not sure & 12 & 13.8 & 13.8 & 13.8 \\
\cline { 2 - 6 } & Strongly disagree & 6 & 6.9 & 6.9 & 20.7 \\
\hline Disagree & 4 & 4.6 & 4.6 & 25.3 \\
\hline Agree & 48 & 55.2 & 55.2 & 80.5 \\
\hline Strongly agree & 17 & 19.5 & 19.5 & 100.0 \\
\hline Total & 87 & 100.0 & 100.0 & \\
\hline
\end{tabular}

Source: Researcher's own Computations from the questionnaire

\subsection{Employee Perception on Training and Development}

The study also explored how employees perceive training and development to organizational performance. From the results in Table 19 and Figure 17, 33.3\% highlighted that there was relatedness of T\&D to organizational performance, $14.9 \%$ somewhat related and $9.2 \%$ was not clearly related. On the other hand, $29.9 \%$ were neutral whilst the $12.6 \%$ said there was no relatedness. In general, the results indicate mixed feelings on whether there was relationship between $\mathrm{T} \& \mathrm{D}$ and organizational performance. However, the majority concur with Obi-Anike, \& Ekwe (2014) who echoed that training and development has a positive relationship with organizational performance. Training and development, therefore, brings about skills, knowledge in employees, who then transfer in building organizational performance through sales, productivity, and improvement in profits.

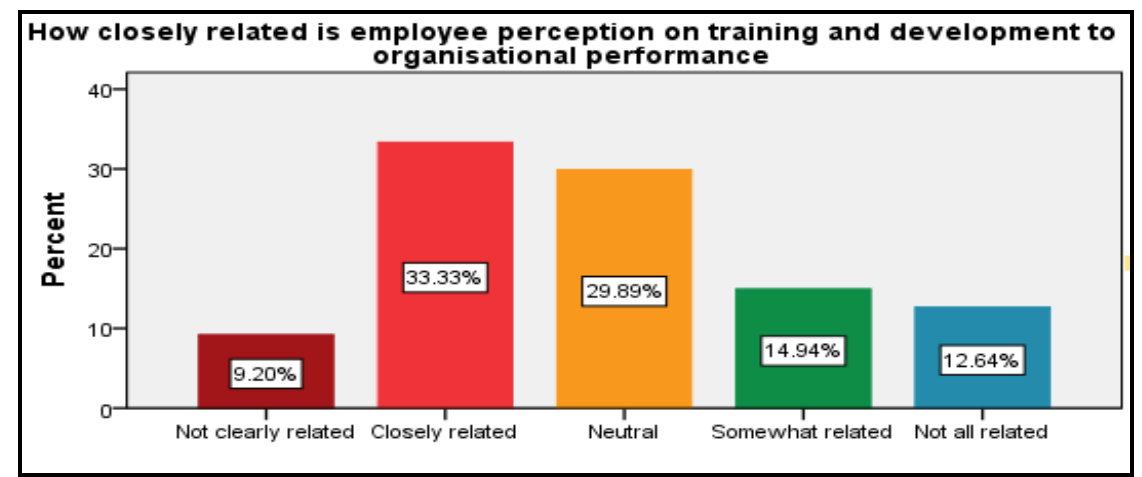

Figure 17. Employee perception on training and development

Source: Researcher's own Computations from the questionnaire 


\section{Macrothink}

International Journal of Human Resource Studies

ISSN 2162-3058 2020, Vol. 10, No. 3

Table 19. Employee perception on training and development

\begin{tabular}{|l|l|r|r|r|r|}
\hline & \multicolumn{1}{|c|}{ Frequency } & Percent & Valid Percent & Cumulative Percent \\
\hline Valid & Not clearly & 8 & 9.2 & 9.2 & 9.2 \\
\hline & & & & 42.5 \\
\hline related & 29 & 33.3 & 33.3 & 72.4 \\
\hline Closely related & 26 & 29.9 & 29.9 & 87.4 \\
\hline Neutral & 13 & 14.9 & 14.9 & 100.0 \\
\hline Somewhat & & & & \\
\hline & related & 11 & 12.6 & 12.6 & \\
\hline Not all related & 87 & 100.0 & 100.0 & \\
\hline Total & & & & \\
\hline
\end{tabular}

Source: Researcher's own Computations from the questionnaire

\subsection{Employee Behavioral Change}

Table 20 and Figure 18 shows the respondents' perception in terms of employee behavior. From the results, 59.8\% agreed that their behavior had changed since enrolling for T\&D programs whilst $19.5 \%$ strongly agreed. On the other hand, $4.6 \%$ strongly disagreed, $10.3 \%$ disagreed and 5.7\% were not sure. The results concur with Sultan et al., (2012) who argued that there was a number of benefits derived from T\&D by positively enhancing employee' performance though the development of skills, abilities and behavior. The objective of T\&D is thus to master the skills, knowledge and apply in their work.

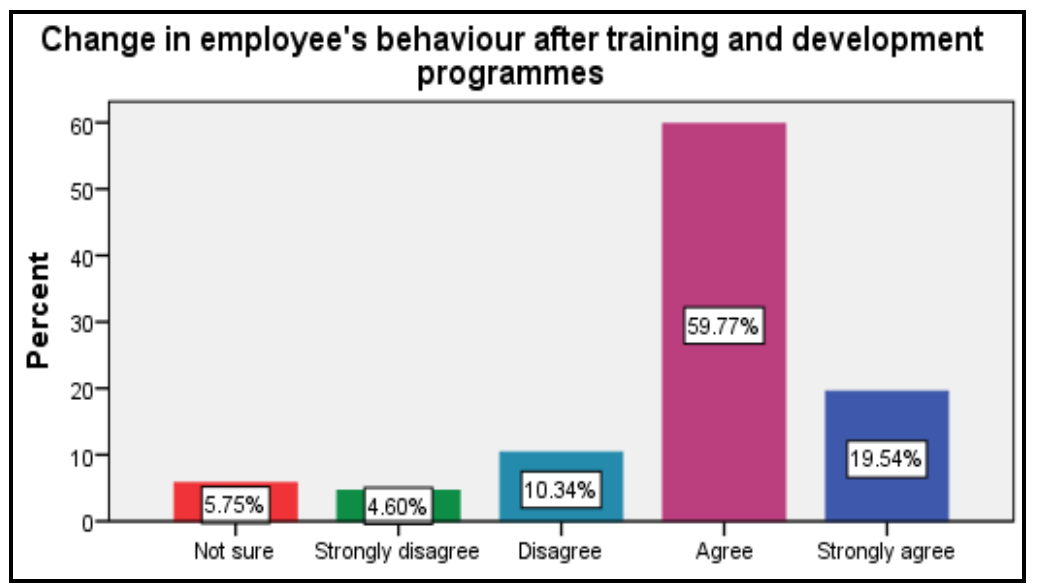

Figure 18. Employee Behavioral Change

Source: Researcher's own Computations from the questionnaire 


\section{Macrothink}

International Journal of Human Resource Studies ISSN 2162-3058 2020, Vol. 10, No. 3

Table 20. Employee Behavioral Change

\begin{tabular}{|l|l|r|r|r|r|}
\hline & Frequency & Percent & Valid Percent & Cumulative Percent \\
\hline Valid & Not sure & 5 & 5.7 & 5.7 & 5.7 \\
\hline $\begin{array}{l}\text { Strongly } \\
\text { disagree }\end{array}$ & 4 & 4.6 & 4.6 & 10.3 \\
\hline Disagree & 9 & 10.3 & 10.3 & 20.7 \\
\hline Agree & 52 & 59.8 & 59.8 & 80.5 \\
\hline Strongly & 17 & 19.5 & 19.5 & 100.0 \\
\hline & & & & \\
\hline
\end{tabular}

Source: Researcher's own Computations from the questionnaire

\subsection{Employees Tackling Obstacles}

Figure 19 and 21 shows how T\&D program has helped employees tackle obstacles easily while performing their duties. From the responses, $62.1 \%$ of the employees agreed that T\&D has assisted in solving problems during their duties, $26.4 \%$ strongly agreed whilst $3.4 \%$ disagreed and $8.0 \%$ were not sure.

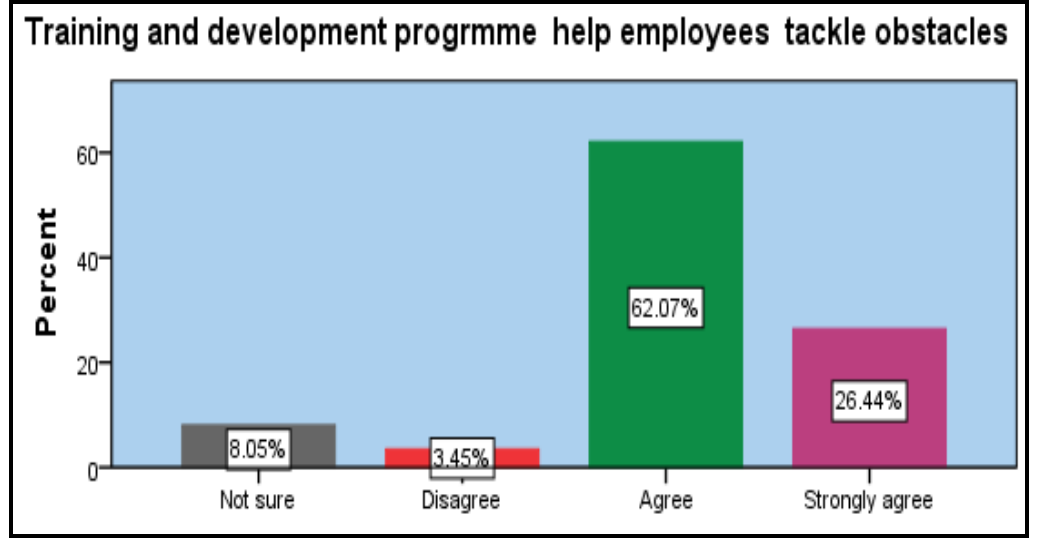

Figure 19. Employees Tackling Obstacles

Source: Researcher's own Computations from the questionnaire

Table 21. Employees Tackling Obstacles

\begin{tabular}{|l|l|r|r|r|r|}
\hline \multirow{2}{*}{ Valid } & Frequency & Percent & Valid Percent & Cumulative Percent \\
\cline { 2 - 6 } & Not sure & 7 & 8.0 & 8.0 & 8.0 \\
\cline { 2 - 6 } & Disagree & 3 & 3.4 & 3.4 & 11.5 \\
\hline \multirow{2}{*}{ Agree } & 54 & 62.1 & 62.1 & 73.6 \\
\hline & Strongly agree & 23 & 26.4 & 26.4 & 100.0 \\
\hline & Total & 87 & 100.0 & 100.0 & \\
\hline
\end{tabular}

Source: Researcher's own Computations from the questionnaire 


\subsection{HRM Record on Service Delivery}

From Table 22 and Figure 20 above, it was agreed by $60.9 \%$ and $6.9 \%$ strongly agreed that the human resource management had recorded changes in the services delivery by the employees that took part in the employee's training and development programs. On the other side, $4.6 \%$ disagreed and $27.6 \%$ were not sure.

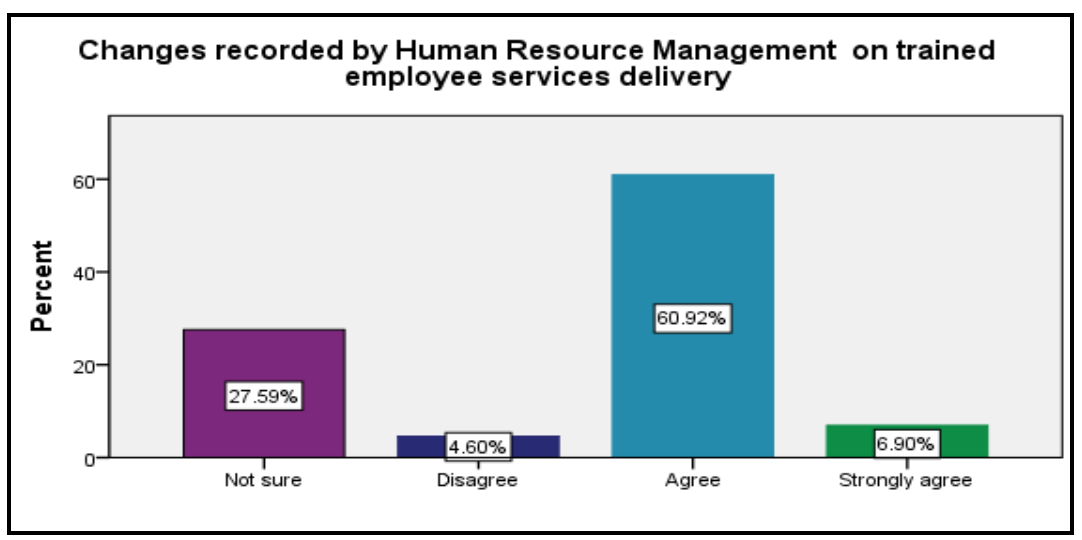

Figure 20. HRM Record on Service Delivery

Source: Researcher's own Computations from the questionnaire

Table 22. HRM Record on Service Delivery

\begin{tabular}{|l|l|r|r|r|r|}
\hline & Frequency & Percent & Valid Percent & Cumulative Percent \\
\hline \multirow{2}{*}{ Valid } & Not sure & 24 & 27.6 & 27.6 & 27.6 \\
\cline { 2 - 5 } & Disagree & 4 & 4.6 & 4.6 & 32.2 \\
\hline & Agree & 53 & 60.9 & 60.9 & 93.1 \\
\hline & Strongly & 6 & 6.9 & 6.9 & 100.0 \\
\hline & agree & & & & \\
\hline
\end{tabular}

Source: Researcher's own Computations from the questionnaire

\subsection{Interpretation and Discussion of Findings}

\subsubsection{Importance of Training and Development to Employees}

The study has shown that T\&D changed employee skills, knowledge, and attitude. This was consistent with Shaheen, Naqvi, and Khan (2013) who stated that T\&D improves employee's knowledge and increases the advantage to network for efficacy and performance. The results were also in line with another study by Nassazi (2013) in that, T\&T positively influences employee' skills, capabilities, and competencies which were needed for better job performance.

The second aspect was that the study has shown that T\&D increased job satisfaction amongst employees. The findings were supported by Adesola, Oyeniyi, and Adeyemi (2013) who claimed that T\&D have been acknowledged as one of the managerial tools that enhances 
employee satisfaction worldwide. Burgard \& Gorlitz (2011) also argued that training has the capability of improving the work environment or encourages networking. Moreover, some employees might enjoy learning because they discover and experience something new as they are getting new ideas. Similarly, training also contributes to job satisfaction as employees learn new things and moved away from daily routines. This view was also supported by Aart, Seema, Bhawnaad, \& Jyoti (2013) that T\&D plays an important role in improving job performance and the effectiveness of employees.

Thirdly, the study reviewed that T\&D enhances employee' performance. The findings support Amin et al. (2013) that T\&D leads to important and better performance for individuals, organization, societies, and teams. They further reiterated that; these benefits span from team, individual performance, and economic prosperity of a country. Smith (2015) also pointed out that employee' training brings motivation and makes employees more productive and innovative. He further argued that training makes sense because well-trained employees were willing and capable of taking control over their jobs with minimum supervision. This means that if there was free management for other tasks, employees respond to customer questions promptly which brings about customer loyalty.

Fourthly, the study indicated that productivity has improved since the introduction of employee' T\&D programs. According to Smith (2015), T\&D plays an important role in building organizations, improving performance as well as increasing productivity. T\&D had been recognized as one of the important catalysts which improves organizational productivity. Further, Konings and Vanormelingen (2009), claimed that T\&D was an important tool that is highly effective when an organization wants to be successful and achieve its objectives thereof resulting in higher productivity. This, however, entails that organizations were ultimately put to compete for the best position and remain on top.

\subsubsection{Relationship between Training and Development to Employee's Performance}

The second section of the study found out that employee' performance played a huge role to the organization. The research revealed that, the organization should invest more in $T \& D$ programs to enhance better performance. The results of the study was in line with the views of Motlokoa, Sekantsi and Monyolo (2017) that it was imperative for organizations to invest into continuous T\&D prgrams to improve employee' skills, knowledge and capabilities required to achieve organizational goals. According to Chinomnso (2014) many organizations have realized how that the success of their companies lies in employee' development. Therefore, these organizations allocate more resources for $\mathrm{T} \& \mathrm{D}$ programs to attain a competitive position.

Secondly, the study also discovered that performance increases the way the NDF officers work with others in the regions. The results go in line with Smith (2015) who viewed that T\&D improves team performance both in the long and short run. Therefore, employees tend to work faster and share ideas from different perspective due to their increased knowledge, skills, and capabilities. Amin et al., (2013) echoes that T\&D leads to important and better performance for individuals, organization, societies, and teams. They further restated that; these benefits span from team and individual performance to economic prosperity of a 
country.

Thirdly, the study reviewed how T\&D has increased client satisfaction within the NDF. The results supported Mthokozosi \& Clifford (2015) view' that investment in T\&D was always geared towards enhancing employee retention, customer satisfaction and the creativity of new products and services. Training can also be viewed in many ways, the focus being to empower employees with knowledge that benefits the organization, customers, and employees (Samwel, 2018). Garcia (2015) further asserted that organizational training policies suggested that the human capital development were directly related to employee, customer, and shareholders' satisfaction as well as an objective to measure organizational performance.

Fourthly, the study found out that T\&D helped employees to carry out their duties effectively. The findings support Saeed \& Asghar (2012) that through the gaining of knowledge, and skills, employees can be assigned on different jobs and were likely to take individual creativities to apply those skills on their daily duties. The findings were also in support of Asim's (2013) study in that, in every organization, employees were the real assets of an organization and if fully trained can do their duties with full dedication an honor.

\section{Conclusions and Recommendations}

T\&D are an old concept but still lives as it changes employees' performance and at the same time organizational performance. The study focused on assessing the impact of training and development on employee performance in the Namibia Defence Force (NDF) at Okahandja. The study employed descriptive research design to draw a sample of 100 employees from a population of 500 employees. Correlation analysis was used to establish relationship between training, development, and employee's performance. The study found out that there was positive relationship between training and development with employee's and NDF performance. It also revealed that employee's performance increased the way the NDF staffs works with other government agencies across the country. Therefore, the NDF should seek to prioritize their training and development (T\&D) programmes based on the training budget and avoid random cost cutting.

Training needs assessment should be conducted in the NDF at least every year to determine the skills gap. Such training need assessments can be possible by ensuring that all supervisors in all departments are well trained and conversant with the procedure and the evaluation of all training programmes. This approach of identifying the skill gaps should be done in a professional manner alongside the line managers and the HR department in charge of T\&D. Further, there should be an agreement from all respective individuals' in terms of what employees are lacking and what training programmes should be offered for employees to improve their performance.

The NDF should provide a recognition programme that focuses on reinforcement of good work performance. Employees who are performing poorly should go through performance appraisal to determine where they are under performing and addressed it. As can be seen from the demographic statistics, more employees only have secondary education certificates. 


\section{Ml Macrothink}

International Journal of Human Resource Studies

ISSN 2162-3058

2020, Vol. 10, No. 3

Therefore, the senior management should encourage personal development through Division of Education and Civil Training for employees to acquire more skills and knowledge in their field of interest. The senior management should, therefore, listen to T\&D initiatives that line managers brings forward for the NDF to have a skilled force. Finally, the NDF should seek to improve employees' morale, engagement, and commitment to perform better in their work and increase productivity. Therefore, it is recommended to structure a motivation policy that was aligned to $T \& D$ programs. It also known that motivation includes intrinsic and extrinsic factors that had to do with remuneration, fringe benefits and so forth.

\section{Acknowledgement}

The authors wish to express their deepest appreciation to the anonymous reviewers and the editor of International Journal of Human Resources Studies for their useful comments and publication of this paper.

\section{References}

Aarti, C., Seema, C., Bhawna, C., \& Jyoti, C. (2013). Job satisfaction among bank employees: an analysis of the contributing variables towards job satisfaction. International Journal of Scientific Technology Research, 2(8), 11-22.

Adesola, M. A., Oyeniyi, K. O., \& Adeyemi, M. A. (2013). Empirical study of the relationship between staff training and job satisfaction among Nigerian banks employees. International Journal of Academic Research in Economics and Management Sciences, 2(6), 108-115. https://doi.org/10.6007/IJAREMS/v2-i6/446

Afshan, S., Sobia, I., Kamran, A., \& Nasir, M. (2012). Impact of training on employee performance: a study of telecommunication sector in Pakistan. Interdisciplinary Journal of Contemporary Research in Business, 4(6), 646-661.

Amadi, E. J. (2014). The effect of training and development on employees' performance, at Safaricom Limited Call Centre. (MBA dissertation). University of Nairobi.

Amin, A., Saeed, R., Lodhi, R. N., Mizna, S., \& Iqbal, A. (2013). The impact of employees training on the job performance in education sector of Pakistan. Middle East Journal of Scientific Research, 17(9), 1273-1278.

Bartel, A. P. (2000). Measuring the employers' return of investments in training: Evidence from the literature. Industrial Relations, 39(3), 502-524. https://doi.org/10.1111/0019-8676.00178

Bhattacherjee, A. (2012). Social Science Research: Principles, Methods, and Practices. Textbooks Collection. Book 3. http://scholarcommons.usf.edu/oa textbooks/3

Bratton, J., \& Gold, J. (2000). Human Resource Management: Theory and Practice, New Jersey: Lawrence Erlbaum Associates, Inc.

Brynard, D. J., Hanekom, S. X., \& Brynard, P. A. (2014). Introduction to Research. $3^{\text {rd }}$ ed, Pretoria: Van Schaik. 
Burgard, C., \& Göerlitz, K. (2011). Continuous training, job satisfaction and gender-an empirical analysis using German panel data, Ruhr Economic Paper No. 265. https://doi.org/10.2139/ssrn.1880937

Bartel, A. P. (2000). Measuring the employer's return on investments in training: Evidence from the literature. Industrial Relations, 39(3), 502-524. https://doi.org/10.1111/0019-8676.00178

Chimonso, B. N. (2014). Effect of Employees Training on Organizational performance in Soft drinks Bottling Companies in Enungu State. (MBA dissertation). University of Nigeria.

García, M. (2005). Training and business performance: The Spanish case. International Journal of Human Resource Management, 16(9), 1691-171.

García, M. (2015). Training and business performance: The Spanish case. International Journal of Human Resource Management, 16(9), 1691-171. https://doi.org/10.1080/09585190500239341

Cole, G. A. (2013). Personal and human resource management. $5^{\text {th }}$ ed., Biddles Ltd: Guide Effort.

Elnaga, A., \& Imran, A. (2013). The Effect of Training on Employee Performance, European Journal of Business and Management, 5(4), 137-147.

Farooq, M., \& Khan, M. A. (2011). Impact of training and feedback on employee performance. Far East Journal of Psychology and Business, 5(2), 23-33.

Garcia, M. (2015). Training and business performance: The Spanish Case. International Journal of Human resource Management, 16(9), 1691-1710. https://doi.org/10.1080/09585190500239341

García, M. (2005). Training and business performance: The Spanish case. International Journal of Human Resource Management, 16(9), 1691-171. https://doi.org/10.1080/09585190500239341

García, M. (2005). Training and business performance: The Spanish case. International Journal of Human Resource Management, 16(9), 1691-171. https://doi.org/10.1080/09585190500239341

George, S. A., \& Scott, B. W. (2012), Managing Human Resource, $16^{\text {th }}$ ed., Cincinnati: South-Western College Publishing.

Gomez-Mejia L. R., Balkin D. B., \& Cardy R. L. (2010). Managing Human Resources. New York: Prentice Hall.

Harrison, R. (2000). Employee development. Pretoria: Beekman Publishing.

Imran, M., \& Tanveer, A. (2015). Impact of training \& development on employees' performance in banks of Pakistan. European Journal of Training and Development Studies, 3(1), 22-44. 
Kauffman, C. (2010) Employee involvement: A new blueprint for success. Journal of Accountancy, 209(5), 46-49.

Konings, J., \& Vanormelingen, S. (2009). The Impact of Training on Productivity and Wages: Firm Level Evidence, Discussion Paper No. 244, Available at SSRN. https://doi.org/10.2139/ssrn.1487468

Kozlowski, S. W. J., Gully, S. M., Brown, K. G., Salas, E., Smith, E. A., \& Nason, E. R. (2001). Effects of training goals and goal orientation traits on multi-dimensional training outcomes and performance adaptability. Organizational Behavior and Human Decision Processes Journal, 85, 1-31. https://doi.org/10.1006/obhd.2000.2930

Leedy, P. D., \& Omrod, J. E. (2010). Practical Research: Planning and Design. $9^{\text {th }}$ ed. New Jersey: Pearson Education.

Makafui R. A. (2014). The effects of training and development on employee performance in the public sector of Ghana, Munich, GRIN Verlag. https ://www.grin.com/document/284725.

Motlokoa, M. E., Selemotsi, L. P., \& Monyolo, R. P. (2018). The impact of training on employee performance: The case of banking sector in Lesotho. International Journal of Human Resource Studies, 8(2), 37. https://doi.org/10.5296/ijhrs.v8i2.12812

Mthokozisi, M., \& Clifford, K. H. (2015). Training and development as a tool for improving basic service delivery; the case of a selected municipality. Journal of Economics, Finance and Administrative Science, 133- 136. https://doi.org/10.1016/j.jefas.2015.10.004

Naanda, R. D. (2010). The integration of identified employability skills into the Namibian vocational education and training curriculum. (MBA dissertation). Stellenbosch University.

Nassazi, A. (2013). Effect of training on employee performance: Evidence from Uganda. (Master thesis). Vaasa University of Applied Sciences, Finland.

Nischithaa, P., \& Narasimba-Rao, M. V. A. L. (2014). The importance of training and development programmes in hotel industry. International Journal of Business and Administration Research Review, April-June 1(5), 50-51.

Noe, R. A. (2008). Employee training and development, $5^{\text {th }}$ ed., New York: McGraw-Hill.

Noe, R. A., Hollenbeck, J. R., Gerhart, B., \& Wright, P. M. (2012). Human resource management: Gaining a competitive advantage. $8^{\text {th }}$ ed. United Kingdom: McGraw-Hill.

Obi-Anike, H. O., \& Ekwe, M. C. (2014). Impact of training and development on organizational effectiveness: Evidence from selected public sector organizations in Nigeria. European Journal of Business and Management, 6(29), 66-75.

Olumuyiwa, O. S., Adelaja, A. S., \& Chukwuemeka, O. E. (2012). Training and development, a vital tool for organizational effectiveness. A case study of Sterling Bank Nigeria, 6(2), 49. https://doi.org/10.9790/487X-0624857

Pieters, L. (2014). The effectiveness of training in public sector organizations: A case study of 
the College of the Arts in Windhoek, (MBA dissertation). University of Namibia.

Raderbauer, M. (2011). The importance of sustainable business practices in the Viennese accommodation industry. (Master thesis). University of Exeter.

Robertson, I., Cooper, C. L., Sarkar, M., \& Curran, T. (2015). Resilience training in the workplace from 2003-2014: A systematic review. Journal of Occupational and Organizational Psychology, 88, 533-562. https://doi.org/10.1111/joop.12120

Saeed, M. M., \& Asghar, M. A. (2012). Examining the relationship between training, motivation, and employees' job performance: the moderating role of person job fit. Journal of Basic and Applied Scientific Research, 2(12), 12177-12183.

Samwel, J. O. (2018). Impact of employee training on organizational performance - Case study of drilling companies in Geita, Shinyanga and Mara Regions in Tanzania. International Journal of Managerial Studies and Research, 6(1), 36-41. https://doi.org/10.20431/2349-0349.0601005

Sandamali, J. G. P., Dinithi-Padmasiri, M. K., Mahalekamge, W. G. S., \& Mendis. M. V. S. (2018). The relationship between training and development and employee performance of executive level: Employees in apparel organizations. International Invention of Scientific Journal, 2(1), 17.

Sanyal, S., \& Hisam, M. (2016). The impact of service quality on customer satisfaction: A study on selected retail stores in India. International Review of Management and Marketing, $6,851-856$.

Sendawula, K., Kimuli, S. N., Bananuka, J., \& Muganga, G. N. (2018). Training, employee engagement and employee performance: Evidence from Uganda's health sector. Cogent Business \& Management Journal, 5, 11. https://doi.org/10.1080/23311975.2018.1470891

Shaheen, A., Naqvi, S. M., \& Khan, M. A. (2013). Employees training and employee organizational performance: Mediation by employees' performance. Interdisciplinary journal of contemporary research in business, 490-503.

Singleton, R. A., \& Straits, B. C. (2010). Approaches to social research, $5^{\text {th }}$ ed. New York: Oxford University Press.

Smith, G. (2015). How to increase job satisfaction and improve employee engagement. Accessed from www.chartcourse.com/articlepride.htm.

Sultana, A., Irum, S., Ahmed, K., \& Mehmood, N. (2012). Impact of training on employee performance: A study of telecommunication sector in Pakistan. Interdisciplinary Journal of contemporary research in business, 4(6), 646-661.

Tshikovhi, R. E. (2012). Training and development programme: Performance of employees at South African Platinum Mine. (Master dissertation). University of South Africa.

Welman, C., Kruger, F., \& Mitchell, B. (2009). Research Methodology. $3^{\text {rd }}$ ed. South Africa: Oxford University Press. 


\section{Macrothink}

International Journal of Human Resource Studies

ISSN 2162-3058 2020, Vol. 10, No. 3

Wright, P., \& Geroy, D. G. (2001). Changing the mindset: the training myth and the need for word-class performance. International Journal of Human Resource Management, 12(4), 586-600. https://doi.org/10.1080/09585190122342

\section{Appendix A}

Questionnaire for the Study on "The impact of Training and Development on Employee's Performance in the Namibian Defence Force at Okahandja".

\section{Introduction}

We are conducting a study on "The impact of Training and Development on Employee's Performance in the Namibian Defence Force at Okahandja". Therefore, we would like to humbly request you to take a few minutes despite your busy schedule to complete this questionnaire. Participation in this study is completely voluntary and anonymous. We promised that all information gathered shall be used for academic purposes only and treated with confidentiality.

\section{Structure of the Questionnaire}

The Questionnaire consisted of four sections. Section A consists of demographic information and Section B contained questions to investigate the importance of training and development to employees. Section $C$ examines the significance of employee performance to the organization and Section D consists of questions to explore the relationship between training and development to employees' performance.

\section{Section A: Demographic information}

1. Gender

\begin{tabular}{|l|l|}
\hline Male & Female \\
\hline & \\
\hline
\end{tabular}

2. Age groups

\begin{tabular}{|l|l|}
\hline $18-30$ & \\
\hline $31-40$ & \\
\hline $41-50$ & \\
\hline 51 and above & \\
\hline
\end{tabular}

3. Educational Level

\begin{tabular}{|l|l|}
\hline Primary & \\
\hline Secondary & \\
\hline Diploma & \\
\hline Graduate & \\
\hline
\end{tabular}

4. Number of years in the NDF

\begin{tabular}{|l|l|}
\hline $1-5$ & \\
\hline
\end{tabular}




\begin{tabular}{|l|l|}
\hline $6-10$ & \\
\hline $11-15$ & \\
\hline $16-20$ & \\
\hline 21 and above & \\
\hline
\end{tabular}

5. Category of position

\begin{tabular}{|l|l|}
\hline Senior management (Colonel- Brigadier General) & \\
\hline Middle management (Lieutenant Colonel-Major) & \\
\hline Junior management (Lieutenant-Warrant Class 2) & \\
\hline Other ranks (Private-Staff Sergeant) & \\
\hline
\end{tabular}

7. How often do you go for training each year?

\begin{tabular}{|l|l|}
\hline 1 time & \\
\hline 2 times & \\
\hline 3 times & \\
\hline 4 times & \\
\hline
\end{tabular}

\section{Section B: Importance of training and development to employees}

8. Training and development have changed employee's skills, knowledge, and attitude.

\begin{tabular}{|l|l|l|l|l|}
\hline Agree & Strongly Agree & Disagree & Strongly Disagree & Not Sure \\
\hline & & & & \\
\hline
\end{tabular}

9. The training and development programme have increased job satisfaction among employees.

\begin{tabular}{|l|l|l|l|l|}
\hline Agree & Strongly Agree & Disagree & Strongly Disagree & Not Sure \\
\hline & & & & \\
\hline
\end{tabular}

10.Training is essential for the intellectual grown of NDF departments in the regions.

\begin{tabular}{|l|l|l|l|l|}
\hline Agree & Strongly Agree & Disagree & Strongly Disagree & Not Sure \\
\hline & & & & \\
\hline
\end{tabular}

11.The training and development programmes have impacted the NDF employees positively to perform better.

\begin{tabular}{|l|l|l|l|l|}
\hline Agree & Strongly Agree & Disagree & Strongly Disagree & Not Sure \\
\hline & & & & \\
\hline
\end{tabular}

12.Productivity has improved since the introduction of employee training and development programmes.

\begin{tabular}{|l|l|}
\hline Yes & No \\
\hline & \\
\hline
\end{tabular}




\section{Section C: Significance of employee performance to an organization}

13. NDF should invest more in training programmes to enhance better performance.

\begin{tabular}{|l|l|l|l|l|}
\hline Agree & $\begin{array}{l}\text { Strongly } \\
\text { Agree }\end{array}$ & Disagree & $\begin{array}{l}\text { Strongly } \\
\text { Disagree }\end{array}$ & Not Sure \\
\hline & & & & \\
\hline
\end{tabular}

14. Performance will increase the way NDF officers work with others in their regions.

\begin{tabular}{|l|l|l|l|l|}
\hline Agree & Strongly Agree & Disagree & Strongly Disagree & Not Sure \\
\hline & & & & \\
\hline
\end{tabular}

15.Less errors have been recorded since taking part in the training and development programmes.

\begin{tabular}{|l|l|l|l|l|}
\hline Agree & Strongly Agree & Disagree & Strongly Disagree & Not Sure \\
\hline & & & & \\
\hline
\end{tabular}

16.Employee training and development has increased client satisfaction within the NDF.

\begin{tabular}{|l|l|l|l|l|}
\hline Agree & Strongly Agree & Disagree & Strongly Disagree & Not Sure \\
\hline & & & & \\
\hline
\end{tabular}

17.How has training and development programmes helped the NDF officers to carry out their duties?

\begin{tabular}{|c|c|c|c|c|}
\hline Good & Better & Excellent & Poor & Not Sure \\
\hline & & & & \\
\hline
\end{tabular}

\section{Section D: Relationship between training and development to employees' performance}

18.Employee perception on training and development is correlated to organizational performance

\begin{tabular}{|l|l|l|l|l|}
\hline Agree & Strongly Agree & Disagree & Strongly Disagree & Not Sure \\
\hline & & & & \\
\hline
\end{tabular}

19.How closely related is employee perception of training and development to organizational performance?

\begin{tabular}{|l|l|l|l|l|}
\hline Not all related & Somewhat related & Neutral & Closely related & $\begin{array}{l}\text { Not closely } \\
\text { related }\end{array}$ \\
\hline & & & & \\
\hline
\end{tabular}

20.Many employees' behaviour changed since enrolling for the employee's training and development programmes.

\begin{tabular}{|l|l|l|l|l|}
\hline Agree & Strongly Agree & Disagree & Strongly Disagree & Not Sure \\
\hline & & & & \\
\hline
\end{tabular}


21.The training and development programme have changed the employees' perspective of their jobs.

\begin{tabular}{|l|l|l|l|l|}
\hline Agree & Strongly Agree & Disagree & Strongly Disagree & Not Sure \\
\hline & & & & \\
\hline
\end{tabular}

22.The employee training and development programme has helped them tackle obstacles easily while performing their duties.

\begin{tabular}{|l|l|l|l|l|}
\hline Agree & Strongly Agree & Disagree & Strongly Disagree & Not Sure \\
\hline & & & & \\
\hline
\end{tabular}

23.The Human Resources Management has recorded changes in the services delivery by the employees that took part in the employee's training and development programmes.

\begin{tabular}{|l|l|l|l|l|}
\hline Agree & Strongly Agree & Disagree & Strongly Disagree & Not Sure \\
\hline & & & & \\
\hline
\end{tabular}

24. What recommendations would you give to the organization for it to improve its training and development programs?

Thank you for taking part...!

\section{Copyright Disclaimer}

Copyright for this article is retained by the author(s), with first publication rights granted to the journal.

This is an open-access article distributed under the terms and conditions of the Creative Commons Attribution license (http://creativecommons.org/licenses/by/4.0/). 